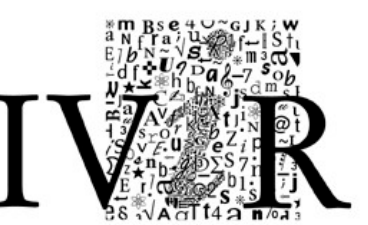

Institute for Information Law

FACULTY OF LAW - UNIVERSITY OF AMSTERDAM

\title{
The digitisation of cultural heritage: originality, derivative works and
} (non) original photographs

\section{Thomas Margoni}

Contact information:

dr. T. Margoni

t.margoni@uva.nl

Institute for Information Law

University of Amsterdam

Korte Spinhuissteeg 3

1012 CG Amsterdam

www.ivir.nl

\section{Keywords:}

EU copyright law, cultural heritage, originality, derivative works, photographic works, non original photographs, right of adaptation

This publication is released under a CCPL BY-SA 4.0 license

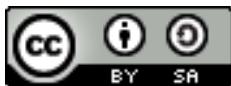




\title{
The digitisation of cultural heritage: originality, derivative works
}

\author{
and \\ (non) original photographs \\ Thomas Margoni \\ Institute for Information Law (IViR) - Faculty of Law \\ University of Amsterdam
}

\section{Table of Content}

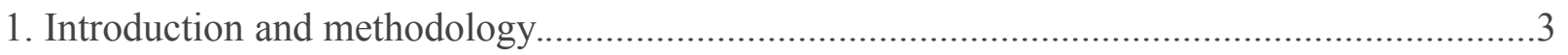

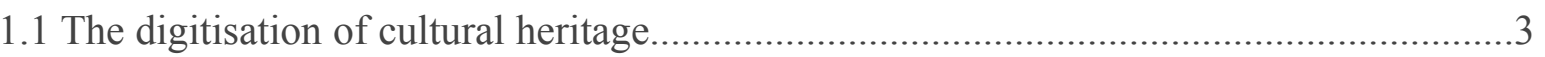

1.2. Research Question, Scope and Methodology........................................................

Part I - General Principles

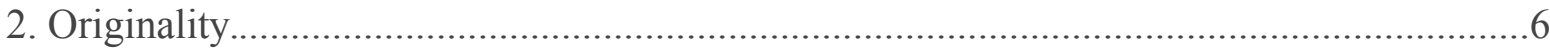

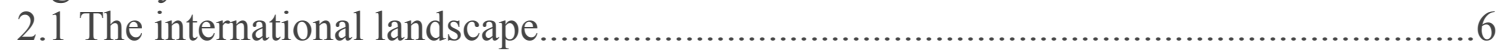

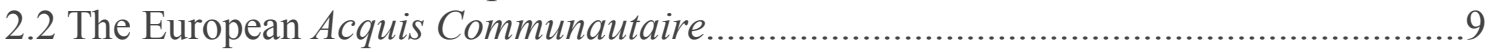

2.2.1) The vertically harmonised standard of originality in EU copyright law..........10

a) Software

b) Photographs

c) Database

2.2.2) The ECJ and the "horizontal" expansion of the originality standard..............14

2.2.3) The effects of AOIC on Member State domestic laws.....................................16

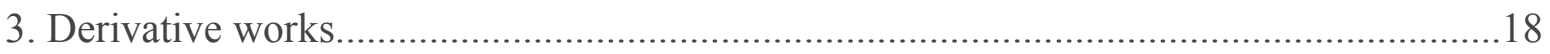

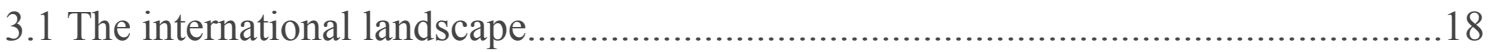

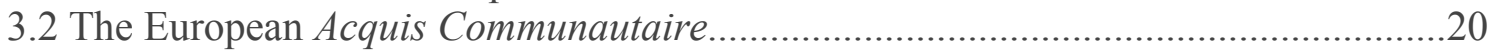

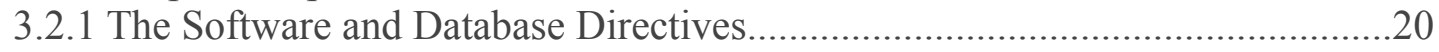

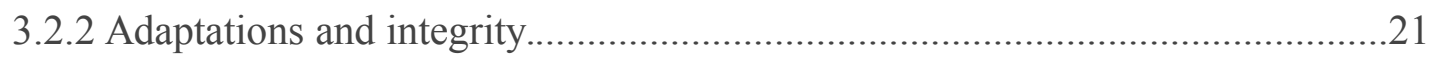

3.2.3 The Court of Justice and the European Commission on the right of adaptation.

a) Allposter $v$ Stichting Pictoright

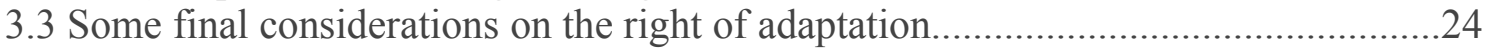

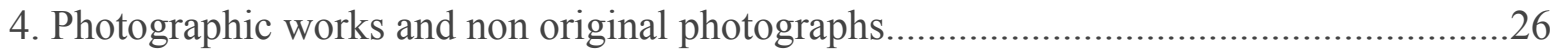

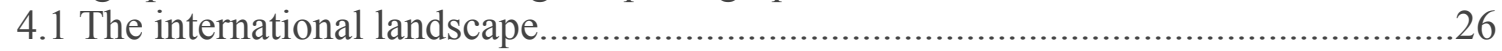

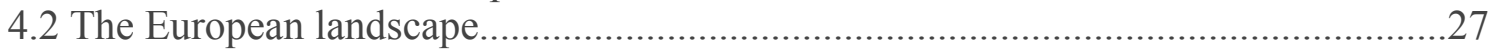


Part II - Country Overview

5. Germany.

5.1 Originality

5.2 Derivative works

5.3 Photographic works and non original photographs

6. France.....

6.1 Originality

6.2 Derivative works

6.3 Photographs and non original photographs

7. Spain

7.1 Originality

7.2 Derivative works

7.3 Photographic works and non original photographs

8. Italy.

8.1 Originality

8.2 Derivative works

8.3 Non original photographs

9. Poland

9.1 Originality

9.2 Derivative works

9.3 Photographic works and Non original photographs

10. UK.

10.1 Originality

10.2 Derivative works

10.3 Photographic works and non original photographs

11. The Netherlands.

11.1 Originality

11.2 Derivative works

11.3 Photographic works and non original photographs

Part III - Conclusions and recommendations

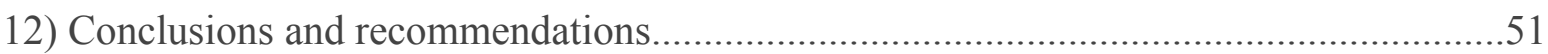

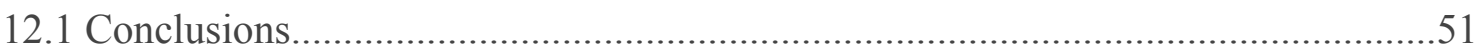

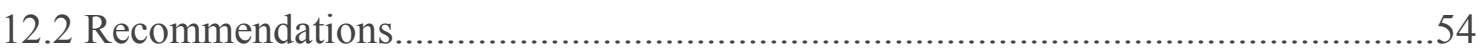

12.2.1) For Cultural Institutions

12.2.2 For EU and MS legislatures

Bibliography

Annex I - Tables

Annex II - Questionnaire..

Annex III - List of national correspondents. 


\section{Introduction and methodology}

\subsection{The digitisation of cultural heritage}

The purpose of this paper is to explore the legal consequences of the digitisation of cultural heritage institutions' archives and in particular to establish whether digitisation processes involve the originality required to trigger new copyright or copyright-related protection. ${ }^{1}$

Frequently, cultural institutions participating in digitisation projects are not fully aware of whether they possess, or could posses, specific rights stemming from the activity of turning their "physical" catalogue into a "digital" one. Consequently, they often claim not to be in the legal position to recognise that the digitised representations of the originals are in the public domain or, on the contrary, whether the digitisation process created a new primary or derivative work or other protected subject matter and whom they belong. ${ }^{2}$ The situation is further complicated by the varying status of the items that are digitised: the latter can be in the public domain or constitute protected subject matter in their own right, a condition that may not only influence the final result but the same possibility to proceed to digitisation in absence of specific authorisation. ${ }^{3}$

At the same time, many cultural institutions (but not all of them, see the example of the Rijksmuseum ${ }^{4}$ ) express the concern that allowing an unrestricted reproduction and digitisation of the works in their collections would deprive them of an important source of income, which is a compelling issue especially during periods of dire financial crisis and of cutting of public funding to

1 The focus of the study is on the digitisation of "texts" (including books, newspapers, letters, manuscripts, etc), "images" (including paintings, drawings, maps, photos, etc), and "objects" (including statues, sculptures, vases, coins, etc.). Importantly, the study concentrates on the copyright or copyright related status of digitised items individually considered and therefore the issue of whether the digitised collection can trigger database rights (copyright or sui generis) is outside the scope of this study.

Cultural heritage institutions' ability to digitise their collections is largely based on the public domain status of the latter. When the copyright, or at least the rights of economic exploitation, elapse, acts such as those here under scrutiny can be performed without the need to secure authorisation. Alternatively, when the items forming the collections are protected by copyright or related rights to copyright two possibility are available: relying on fair use/dealing or other Exceptions or Limitations to Copyright (ELC) or seek the authorisation of the copyright holder.

Authorisations required on a legal basis other than the one identified in the research question are not considered in this study, although they may represent an impediment to digitisation projects. In particular, claims based on database rights (copyright and sui generis), unfair competition, misappropriation, PPP agreements and other special forms of protection are outside the scope of this study. An example of special forms of protection are "Cultural Heritage Codes" requiring the authorisation of the competent Ministry for acts such as reproductions of items listed as cultural heritage. The functioning of these codes, considerations related to the fact that they may reintroduce a copyright-like form of protection for public domain works not contemplated by the aquis communautaire, and whether this is a power resting with MS or it has been pre-empted by EU copyright law are also not discussed in this paper. For an account regarding the basic traits of the Italian and Greek Cultural Heritage Codes, see Morando 2011.

$4 \quad$ See Pekel 2014. 
cultural institutions. ${ }^{5}$ Many online projects dealing with digital images of (often public domain) works such as paintings and objects of art are constantly facing claims connected with the status of those digital representations. Examples can be seen in the operations of Europeana and in some extra-judicial cases involving Wikipedia $^{6}$

Likewise, in a recent document, the European Commission (EC) stated that a large number of Member States (MS) "reported obstacles in ensuring that public domain material remains in the public domain after digitisation, mainly in connection with photos and photographers' rights". ${ }^{7}$ Furthermore, the report indicates that "the complex issue of a new layer of rights triggered by the digitisation process itself in some cases is mentioned as a potential source of legal uncertainty. The fear of losing control, use of public domain material to generate income and difficulties to assert public domain status were also reported as possible obstacles ...". The Commission concludes that "the legal stand of some digital reproductions of public domain works lacks clarity and requires further attention". ${ }^{8}$ Similar concerns pointing to the fact that the "public domain content in the analogue world should remain in the public domain in the digital environment" have been expressed by the High-Level Expert Group on Digital Libraries in 2008. ${ }^{9}$

In the light of these and similar concerns, this paper attempts to clarify the copyright situation originating from digitisation projects which, as the Commission and many MS reported, are cause of legal uncertainty. A major role in this legally uncertain field is played by the standard of originality which is one of the main requirements for copyright protection. Only when a subject matter achieves the requested level of originality, it can be considered a work of authorship. Therefore, a first key issue analysed in this study is whether - and under which conditions digitisation activities can be considered to be original enough as to constitute works (usually a photographic work) in their own right. A second element of uncertainty is connected with the type of work eventually created by acts of digitisation. If the process of digitisation of a (protected) work can be considered authorial, then the resulting work will be a derivative composed by two works: the original work digitally reproduced and the - probably - photographic work reproducing it. Finally, a third element of uncertainty is found in the protection afforded to "other photographs" by the last sentence of Art. 6 Term Directive and implemented in a handful of European countries.

\subsection{Research Question, Scope and Methodology}

The main research question addressed in this study is the following:

Do acts of digitisation of physical items create new copyright or related rights (e.g. non original photographs)?

$5 \quad$ For an analysis of the relationship between Cultural Heritage Institutions, the Public Domain and Public Sector Information, see Communia Policy Paper n.8 "Re-use of public sector information in cultural heritage institutions", November 2014, available at: http://www.communia-association.org/policy-papers-2/\#policy8

6 See e.g. the National Portrait Gallery and Wikimedia Foundation copyright dispute described at https://en.wikipedia.org/wiki/National_Portrait_Gallery_and_Wikimedia_Foundation_copyright_dispute.

7 See the Report on the Implementation of Commission Recommendation 2011/711/EU - Progress Report 2011-2013 of September 2014 "Digitisation, online accessibility and digital preservation", available at https://ec.europa.eu/digitalagenda/en/news/european-commissions-report-digitisation-online-accessibility-and-digital-preservation-cultural, at 22.

8 Id

${ }^{9}$ See High Level Expert Group on Digital Libraries Sub-group on Public Private Partnerships, Final Report on Public Private Partnerships for the Digitisation and Online Accessibility of Europe's Cultural Heritage, May 2008. 
In order to address this question the paper is divided into three parts. Part I is dedicated to the analysis of copyright law key concepts such as the originality standard, the definition of derivative works and the forms of protection available in cases of digital (or film-based) representations of objects (photographs).

The second part of the study is devoted to a survey of a selection of EU Member States in an attempt to verify how the general concepts identified in Part I are applied by national legislatures and courts. The selected countries are Germany, France, Spain, Italy, Poland, the Netherlands and the UK. The country analysis fulfils a double function: on the one hand it provides a specific overview of the national implementation of the solutions found at international and EU level. On the other hand, it constitutes the only possible approach in order to analyse the protection afforded by some MS to those "other photographs" (also called non original photographs or mere/simple photographs) provided for by the last sentence of Art. 6 Copyright Term Directive. ${ }^{10}$ Part III presents some conclusions and recommendations for cultural heritage institutions and for legislatures.

The paper's working hypothesis postulates that in a vast majority of situations digitisation processes do not attract, nor should attract, any form of protection based on copyright and related rights. ${ }^{11}$ Nonetheless, in some cases, protection afforded by copyright and by the neighbouring right protecting "other" photographs may be available. The turning point is the distinction between a mere act of reproduction (which for copyright purposes may constitute a right of economic exploitation of a protected work) and an act that creates something new (a new original or derivative work or another type of subject matter such as "other" photographs).

The chosen methodology is mixed. The main research activity was based on desk research of relevant legislation, case law, policy documents and literature at international, EU and MS level following a comparative method. This was integrated with a questionnaire administered to selected legal experts in the 28 EU countries. The list of national correspondents and of covered countries is available as Annex II.

The questionnaire was divided in two parts. Part I asked four open ended questions on the identified fundamental concepts of copyright law: originality, derivative works, original photographs and neighbouring rights. Part II was based on a hypothetical case study where three different scenarios were tested. Respondents were asked a number of multiple choice questions. The three scenarios, while certainly over-simplifying the complex and idiosyncratic dynamics that digitisation activities follow, identified and summarised some of the most common characteristics of digitisation processes.

The first scenario, labelled "automated digitisation" was described as "Automated digitisation realised in absence (or negligible presence) of human intervention (e.g.: Google scanning automatically all books of the entire collection)". The second scenario, labelled "semi-automated digitisation" was described as "Automated digitisation realised by a human operator (e.g.: human operator taking pictures/manually photocopying collections for inventory/classificatory purposes)".

10 See Directive 2006/116/EC on the term of protection of copyright and certain related rights (codified version); Art 6 reads: "Photographs which are original in the sense that they are the author's own intellectual creation shall be protected in accordance with Article 1. No other criteria shall be applied to determine their eligibility for protection. Member States may provide for the protection of other photographs".

11 This does not mean that under specific circumstances remedies based on other causes of action, such as unfair competition, misappropriation, breach of confidence, or sometimes even trade marks, are excluded. However, their eventual availability is not strictly related with the originality, or lack thereof, in the acts of digitisation and is therefore outside the scope of the present study. 
The third scenario, called "human digitisation" was described as "Digitisation operated by a specifically hired professional with the objective to realise high quality outputs (e.g.: photographer taking different shots in different light conditions to create hi-resolution images to be made available on the institution's website)".

The questionnaire is available as Annex II.

The results of the questionnaires were of fundamental assistance in the completion of the study. Furthermore, correspondents contributed by providing documents that were not available in English or in the other languages known to the author. Where correspondents have provided specific documents and helped with translations, this is acknowledged in the study. That being said, all the possible mistakes are the responsibility of the author alone.

\section{Part I - General Principles}

\section{Originality}

\subsection{The international landscape}

Originality is an essential requirement of copyright law: only works that show some minimum amount of this attribute attract protection. Yet, generally speaking, originality lacks a precise statutory definition. ${ }^{12}$ None of the major international copyright treaties explicitly define what it is and which level it has to reach in order to enable copyright to arise, bringing a leading scholar in the field to state that "So far as a particular threshold standard for protection is concerned, the requirements [of the Berne Convention] arise chiefly as a matter of inference, requiring the reader to work through a number of different provisions". ${ }^{13}$ Indeed, the Berne Convention for the protection of artistic and literary works of $1886^{14}$, the oldest and most relevant Convention in the field, only postulate a general requirement of originality indirectly and implicitly. Art. 2(1) of the Convention dedicated to "Protected Works" merely establishes that:

12 See generally Ricketson \& Ginsburg, 2006, especially at 8.05; Bently \& Sherman, 2014, at 93; Cornish, Llewelyn \& Aplin, 2013, at 11-04; Gervais \& Judge, 2005, at 16; Goldstein \& Hugenholtz, 2013, at 192; Ginsburg, 1992; Gervais, 2002; Gravells, 2007; Judge \& Gervais, 2010; Schricker 1995.

13 See Ricketson 2009, at 59.

14 See Berne Convention for the Protection of Literary and Artistic Works of September 9, 1886 revised in Paris on July 241971 and amended on September 28, 1979 (Berne Convention Paris Text). 
"[T]he expression "literary and artistic works" shall include every production in the literary, scientific and artistic domain, whatever may be the mode or form of its expression ..."

The same Article then provides an illustrative list of works included in such a broad definition. Books and other writings, lectures, choreographic works, musical compositions with or without words, cinematographic works, works of drawing, painting, architecture, sculpture, engraving, photographic works, works of applied art, illustrations, maps and plans are all examples of protected works. Similar lists are found in most national Copyright Acts. ${ }^{15}$

As it can be seen, "originality" is not explicitly mentioned as a requirement in the general clause or in the list present in Art. 2(1). ${ }^{16}$ All the same, the word "original" is not completely absent from the Convention. It can be found in Art. 2(3) dealing with "translations, adaptations, arrangements ... and other alterations", which are protected as original works. ${ }^{17}$ A similar provision is present in Art. 14-bis dealing with cinematographic works. ${ }^{18}$

Another useful element related to the presence of an originality element in Berne can be found in Art. 2 Section 5 which reads:

"Collections of literary or artistic works such as encyclopaedias and anthologies which, by reason of the selection and arrangement of their contents, constitute intellectual creations shall be protected as such, without prejudice to the copyright in each of the works forming part of such collections"

Similarly to the above mentioned case of translations, collections of literary or artistic works can be protected as autonomous - yet derivative - forms of expression. Not every collection is eligible, though: only those that by reason of the selection or arrangement of their contents constitute "intellectual creations". ${ }^{19}$ This last expression does not only states that a form of originality is necessary in order to trigger protection, but it also gives some more information regarding the type of originality required: intellectual creations.

The requisite of "intellectual creations" is noteworthy as it does not only apply to Art. 2(5), i.e. to collections of literary and artistic works, but it extends to all the subject matter covered by Art. $2 .^{20}$ It has been said that an explicit definition of "intellectual creations" was indispensable only for the case of Art. 2(5), because the originality inherent in collections, as opposed to that in the works

15 See infra Part II.

16 See Ricketson \& Ginsburg 2006, at 8.87.

17 The word "original" is used twice in the same article 2(3) with two different meanings "Translations, adaptations, arrangements of music and other alterations of a literary or artistic work shall be protected as original works without prejudice to the copyright in the original work". This should not lead to any confusion as the plain meaning of the article is clear; See Ricketson \& Ginsburg, 2006, at 8.87

18

9 As it is well known, the English version of the Berne Convention incorrectly reports "selection AND arrangement" however the original official French text speaks of "selection OR arrangement", and this is the version that in case of contrast prevails. Therefore, even if the English translations still nowadays reports AND, the real requirement is - and has always been - OR; See Ricketson \& Ginsburg, 2006, 8.87.

20 "A line therefore seems to run from art.2(5) through art.2(3) to art.2(1) as follows: "original translations, adaptations, etc." under art.2(5) and collections of works that are "intellectual creations" under art.2(3) are to be protected as "literary and artistic works" under art.2(1), suggesting that both originality and intellectual creation are correlative and implicit requirements for literary and artistic productions that otherwise fall under art.2(1)"; See Ricketson 2009, at 57. 
collected, "may not be as readily discernible". ${ }^{21}$ Accordingly, not only collections but also any other scientific or literary work such as books, lectures, musical compositions, songs, works of photography, and sketches, in order to comply with Berne standards have to possess the required type of originality, i.e. they have to be intellectual creations. ${ }^{22}$ What this exactly entails, how high or low - the level of originality is, and what are the tests, standards, and elements that can fill-up with content the concept of intellectual creation is, however, a matter for national legislatures and courts. $^{23}$

Traditionally, common law countries have phrased the requirement of originality in the sense that the work must originate with the author, i.e. must not be copied, and it must be the result of "skill, judgement and/or labour" or of his "sweat of the brow". ${ }^{24}$ Within those countries, the US and Canada developed their own standards. ${ }^{25}$ The U.S. after Feist require a modicum of creativity which implies a higher degree of originality than the traditional skill, judgement and labour. ${ }^{26}$ In Canada the Supreme Court in $\mathrm{CCH}$ created a new standard that in the same words of the Court is higher than the one historically applied in the UK but does not require creativity as in the U.S. ${ }^{27}$ Other countries of this family, e.g. Australia and the same UK, have likewise adjusted their own standard. ${ }^{28}$

Countries belonging to civil law traditions, instead, have shown the tendency to stress the personal dimension or personal input that the author puts into the work. ${ }^{29}$ This difference, however, should not be misinterpreted, as often it is more declamatory than material. Historically, a rather low level of originality can be seen also in civil law countries, especially in relation to certain subject matter such as catalogues or technical manuals (e.g. kleine Münze or petite monnaie). ${ }^{30}$

These different conceptualizations of originality are all compatible with the Berne mandated requisite of "intellectual creations" since, as it has been noted, the determination of the precise meaning is left to national laws and tribunals. While it is arguable that the product of the "sweat of the brow" may be less "creative" than that of an "oeuvres de l'esprit" or of a "minimum of creativity", it is fundamental to consider the extremely high variance not only within the same legal tradition but even within the same legal system of what has been held protectable in different historical periods. ${ }^{31}$

21 Id; See Gervais, 2002.

22 This corresponds also to the view of the ECJ, see Infopaq, at 34.

23 Id.; Gervais, 2002; Ginsburg, 1992.

24 This is the classical formula historically employed by courts in common law countries and especially in the UK, although the precise wording varied over time adding or substituting elements; See Bently \& Sherman, 2014, at 96; Cornish, Llewelyn \& Aplin, 2013, at 11-04. As it is known the US requires a minimum of creativity; See Feist Publications, Inc. v. Rural Tel. Serv. Co., 499 U.S. 340, 346 (1991); Nimmer, 2014, at Sec. 2.08. The Canadian Supreme Court more recently has embraced a standard which lies between the lower end of the skill and judgment - also known as "sweat of the brow" doctrine" - and the US standard of creativity; See CCH Canadian Ltd. v. Law Society of Upper Canada, [2004] 1 S.C.R. 339; Gervais, 2002.

31 For an analysis of the philosophical traditions justifying copyright (and intellectual property rights more generally) see generally Gordon, 1993; Merges, 2007. 
A last important aspect deserving attention is that the required level of originality, the intellectual creation, has to be present in the expression of an idea, not in the idea itself. This basic principle is once again only implicitly enshrined in the Berne Convention which, as seen, only states that:

"The expression "literary and artistic works" shall include every production in the literary, scientific and artistic domain, whatever may be the mode or form of its expression, such as ..."

A more explicit statement in this sense can be found in Art. 2 of the WIPO Copyright Treaty (WCT) of 1996, and in the specular Art. 9(2) of the Agreement on Trade Related Aspects of Intellectual Property Rights (TRIPS) of 1994 which respectively establish that:

\author{
"Copyright protection [shall] extend[s] to expressions and not to ideas, \\ procedures, methods of operation or mathematical concepts as such". ${ }^{32}$
}

According to this basic principle of copyright law, it is not sufficient that an original idea takes shape in the mind of an author, but that idea needs to be expressed in an original form that can be perceived by others; this principle is also known as the idea-expression dichotomy. ${ }^{33}$

\title{
2.2 The European Acquis Communautaire
}

As seen in the previous chapter, the standard of originality has always been a matter of national law. Different jurisdictions have traditionally implemented different standards, which have varied from country to country. Moreover, within the same country variations are observable in function of the specific period of time and subject matter.

Until relatively recently, EU law did not regulate the standard of originality, nor copyright more generally. The reason for this situation can be found in the absence of a clear and direct attribution of powers to the EU to regulate copyright (principle of conferral). ${ }^{34}$ Since its creation, and until recently, the main basis for EU intervention in the field of copyright were Articles 26 and 114 of the Treaty on the Functioning of the European Union (TFEU), ${ }^{35}$ which have given the EU the competence to respectively adopt measures with the aim of establishing or ensuring the functioning

32 See Art. 2 "Scope of copyright protection" of the World Intellectual Property Organization (WIPO) Copyright Treaty, adopted in Geneva on December 20, 1996; and Art. 9(2) "Relation to the Berne Convention" of the Agreement on Trade-Related Aspects of Intellectual Property Rights (TRIPS), signed in Marrakesh on 15 April 1994, as Annex 1C of the Marrakesh Agreement Establishing the World Trade Organization. The two provisions are virtually identical, with the only difference being the presence of the auxiliary "shall" in the TRIPS definition.

33 See e.g. the U.S Supreme Court decision in Harper \& Row v. Nation Enterprises, 471 U.S. 539 (1985) "copyright's idea/ expression dichotomy strikes a definitional balance between the First Amendment and the Copyright Act by permitting free communication of facts while still protecting an author's expression". A similar statement is present in art. 1(2) of the European Software Directive "protection ... shall apply to the expression ... of a computer program. Ideas and principles ... are not protected". In the ECJ jurisprudence the idea/expression dichotomy can be found in the case Case C 393/09 Bezpečnostni softwarová asociace v Ministerstvo kultury, (BSA) at 49: “... where the expression of those components is dictated by their technical function, the criterion of originality is not met, since the different methods of implementing an idea are so limited that the idea and the expression become indissociable". For an analysis of the concept of authorship in emerging social practices see Bently \& Biron, 2014, at 243.

34 Art. 5 TEU (Treaty on the European Union) enshrines the principle of "conferral" on the basis of which the Union shall act only within the limits of the competences conferred upon it by the Member States in the Treaties. See generally Benabou, 1997. 
of the internal market and the approximation of the laws of Member States. ${ }^{36}$ Eventually, this lack of direct attribution of powers to regulate copyright in a systematic way eventually led to the fragmentary and subject-matter specific approach taken by EU copyright directives, especially during 1990s. ${ }^{37}$

The 1990s, though, also witnessed growing divergences in national originality standards of specific subject matter such as software, a trend that became of major concern for the EC. ${ }^{38}$ The possible obstacles to intra-Community trade and the consequent negative impact on the smooth functioning of the internal market that divergent threshold of originality could entail convinced the Commission to take action in specific fields. However, besides a handful of legislatively harmonised subject matter - which as it will be seen infra comprised software, photographs and databases - the EU legislature did not reach the conclusion that a general and "horizontal" harmonisation of the concept of originality was necessary. ${ }^{39}$

\subsection{1) The vertically harmonised standard of originality in EU copyright law}

The result of the reported lack of direct attribution of powers in copyright law, combined with the internal market relevance of diverging originality standards, led to a "vertical" harmonisation (i.e. through legislative interventions regulating only specifically identified subject matter) of software ${ }^{40}$, databases $^{41}$ and photographs ${ }^{42}$. In recent years, however, that standard has been extended "horizontally" to all kinds of works covered by EU copyright law. This horizontal expansion has been operated by way of interpretation - and not without criticisms - by the European Court of Justice, which established that any work covered by EU copyright law is original if it is the

35 There are other basis for EU legislative intervention in the Treaties, such as Arts. 53 (freedom of establishment), 167 (common cultural heritage), and 169 (consumer protection); nonetheless Art. 114 remains the single principal source of powers used to regulate copyright. See M. van Eechoud, B. Hugenholtz, S. van Gompel, L. Guibault, N. Helberger, 2009, at 1.2.2.

36 The Green Paper on Copyright and the Challenge of Technology - Copyright Issues requiring immediate action, COM(88) 172 , June 1988. Other interventions in the field of intellectual property can be seen in Directive 89/104/EEC on the approximation of trade mark laws (now replaced by Directive 2008/95/EC), and Directive 87/54/EEC on the legal protection of topographies. Recently, Art. 118 was introduced by the Treaty of Lisbon of 2007 empowering the EU to create European intellectual property rights. It must be noted, however, that Art. 118 has enabled the creation of "uniform" intellectual property rights as opposed to "harmonising" the laws of Member States (MS). Accordingly, Art. 118 constitutes the legal basis for the creation of a unitary title, indicatively through a EU Regulation, which is directly applicable in all MS.

37 This can be observed in different documents of the EC. In the 1988 Green Paper, for example, it can be read that the "Commission concluded that a directive on the legal protection of computer programs is a necessary step for the completion of the internal market" and that "the creation of a European information services market, currently divided by juridical and linguistic barriers, is of prime importance"; See Green Paper 1988 at 5.4.1 and 6.2.1.

For a detailed analysis of the EU competences in the harmonisation of copyright law and the role of the internal market see Ramalho, 2014.

39 See Commission Staff Working Paper on the Review of the EC legal framework in the Field of Copyright and Related Rights, SEC(2004) 995.

40 Directive 2009/24/EC of the European Parliament and of the Council of 23 April 2009 on the legal protection of computer programs (Codified version), art. 1(3).

41 Directive 96/9 of the European Parliament and of the Council of 11 March 1996 on the legal protection of databases, art. 3(1).

42 Directive 2006/116/EC of the European Parliament and of the Council of 12 December 2006 on the term of protection of copyright and certain related rights (codified version), art. 6 . 
"author's own intellectual creation". ${ }^{43}$ This section deals with vertical legislative harmonisation, while the horizontal judiciary one is analysed in the next Section.

\section{a) Software}

The concept of "author's own intellectual creation" appeared for the first time in EU copyright law in the Software Directive of 1991. The reasons that brought the EC to require such a standardised level of originality across the EU are explained in the Green Paper of 1988 and relate to the emergence of different standards of protection for software in various EU countries. As the 1988 Green Paper reports, in MS such as France and Germany courts offered protection to software only under specific conditions that differed from the originality standard usually required in those countries for other subject matter. This course of action was a source of concern to the European Commission which interpreted it as a potential threat capable of jeopardizing the internal market. ${ }^{44}$

Nevertheless, the 1988 Green Paper did not provide the final formulation of the "author's own intellectual creation" standard which will eventually be found in the Software Directive. Yet, the Green Paper showed the direction, by pointing to a definition present in the Topography Directive enacted only one year before. ${ }^{45}$ According to that directive, topographies are protected if they are the result of the "creator's own intellectual effort" and are not commonplace in the field. ${ }^{46}$ This concept of originality, it has been argued, is closer to the English and Irish originality standards than to those of continental MS. ${ }^{47}$

As pointed out by Walter and Von Lewinski, the notion of originality underwent different drafting phases and the expression "author's own intellectual creation" appeared for the first time in the Initial Proposal's Explanatory Memorandum and was carried over into the EC Amended Proposal. ${ }^{48}$ The Amended Proposal definition of originality was included into the final text of the Software Directive, in accordance to which a computer program is original if it is the author's own intellectual creation and no other criteria such as qualitative or aesthetic merits should be applied. ${ }^{49}$

In recognizing this approach, the British and Irish standards of originality have probably prevailed over the originality standards of those continental European countries requiring particularly high level of creativity or aesthetic contribution for the protection of software. ${ }^{50}$ Nevertheless, the formula adopted in the Software Directive possesses an undeniable nature of compromise intended to reconcile the British and Irish understanding of originality with that of continental EU countries. ${ }^{51}$ This aspect - it has been argued - can be seen for instance in the choice of words which

43 See van Eechoud, 2012; Bently, 2012; Case C-5/08 Infopaq International A/S v Danske Dagblades Forening, of 16 July 2009 (Infopaq); C-393/09 Bezpečnostní softwarová asociace v. Ministerstvo kultury, of 22 December 2010 (BSA); Joined Cases C403/08 and C-429/08 Football Association Premier League and Others [2011] (FAPL); Case C-145/10 Eva-Maria Painer [2011] (Painer); Case C-604/10 Football Dataco v Yahoo [2012] (Football Dataco v Yahoo).

44 See Green Paper 1988 at 5.6.3 et seq.

45 Directive $87 / 54 /$ EEC on the legal protection of topographies.

46 See Green Paper 1988 at 5.6.7.

47 See Walter \& Von Lewinski, 2010, at 5.1.8. See also the Original Proposal for a Directive on the Legal Protection of Topographies of Semiconductor Products $\operatorname{COM}(85) 775$ final, Ch. 2, Art. 2, n.21 (“Art. 2(3) excludes from protection topographies that ... are not the result of their creator's own intellectual effort, that is, those that are themselves copies ...)"; in a similar direction, the Report on the Proposal from the European Commission for a Directive on the Protection of Original Topographies, produced by the European Parliament, Doc. A 2-88/86 of 16 July 1986, Sec. B, n. 6-7, [Rapporteur Mr. A. Turner].

Id., at 5.1.9.

49 See Recital 8 Directive 91/250/EEC of 14 May 1991; van Gompel \& Lavik, 2013.

50 See Walter \& Von Lewinski, 2010, at 5.1.10 et seq.

51 Id., 5.1.16. 
combines expressions typical of continental European countries (intellectual creations) with those typical of countries such as the UK and Ireland (author's own, in the sense the work must originate with its author, i.e. not being copied). ${ }^{52}$

In the 2000 EC Report on the Implementation of the Computer Program Directive ${ }^{53}$, the EC recognised that the level of originality for software had been harmonised for the first time all over the EU, noting that "12 Member States lower[ed] the threshold for granting protection and the remaining three "lift[ed] the bar". ${ }^{54}$ In particular, the EC noted on the one hand that countries such as Germany had abandoned their previous (higher) requirement of protection for computer programs (Schöpfungshöhe), while on the other hand, the UK had not yet implemented the new EU standard. This lack of compliance with EU law could prove, the EC pointed out, particularly problematic as the UK traditionally offered a lower standard of protection, i.e. skill and labour. ${ }^{55}$

\section{b) Photographs}

The second directive proceeding to a vertical harmonization of the originality standard is the Term Directive, which mandates that photographs which are original in the sense that they are the author's own intellectual creation shall be protected by copyright and that no other criteria should be applied to determine their eligibility for protection (in Art. 6). ${ }^{56}$

The strong similarity to the definition found in the Software Directive is apparent, as it is the character of compromise of the Directive. Not surprisingly, the Software Directive has been used as a reference model especially for the determination of the standard of originality for photographs. ${ }^{57}$

The original directive of $1993^{58}$ stated that in order to achieve a sufficient harmonization of the term of protection - the main goal of that legislative act - photographic works, which due to their artistic or professional character are of importance within the internal market, have to be governed by a harmonised level of originality. ${ }^{59}$ In the 2006 codification of the Term Directive this reference to artistic or professional character disappeared, but it has been submitted that the change has not modified the standard. ${ }^{60}$

An important aspect in the protection of photographs under EU law is to be found in the last sentence of Art. 6 which reads that "Member States may provide for the protection of other photographs". Differently from other "special" forms of protection, the regulation of non original photographs is completely left to MS ${ }^{61}$ While the protection afforded to photographs at the Member State level was particularly inhomogeneous and complicated by the fact that some MS offered a double-tier system of protection, the harmonising effects of this type of provision are not entirely clear. ${ }^{62}$ Allegedly, the explanation for what could be defined as an unsatisfactory approach to harmonisation (since "Le critère d'originalité ... risque de perdre de son importance pratique") is

\footnotetext{
52 Id.

53 Report from the Commission to the Council, the European Parliament and the Economic and Social Committee on the implementation and effects of Directive 91/250/EEC on the legal protection of computer programs COM (2000) 0199 final.

54 Id., at III.

55 Id, at V.1(e).

56 See Art. 6 Directive 2006/116/EC (codified version).

57 See Walter \& Von Lewinski, 2010, at 8.6.10.

58 Directive 93/98/EEC (now repealed) and substituted by Directive . 2006/116/EC).

59 See Recital 17 Directive 93/98/EEC.

60 See Walter \& Von Lewinski, 2010, at 8.6.10.

61 Id. See also Perry \& Margoni, 2011.
} 
probably to be found once again in the character of compromise of the legislative instrument rather than in a clear policy view. ${ }^{63}$ In fact, it has been pointed out that the inclusion of the author's own intellectual creation harmonised standard for photography was "accidental". ${ }^{64}$

At the domestic level, countries that implement a specific neighbouring right protecting non original photographs include Germany, Austria, Spain, Italy and the Scandinavian countries. ${ }^{65}$ The complete lack of harmonising pointers, though, left MS the with widest discretion possible regarding the type of protection. For instance, it has been argued that this legal framework allowed the UK to offer protection to non original photographs under the current wording of the CDPA at the only condition that photographs are not copied ${ }^{66}$ (but see infra for an analysis of the UK situation).$^{67}$

\section{c) Database}

The Database Directive offers copyright protection to databases which, by reason of the selection or arrangement of their contents, constitute the author's own intellectual creation and no other criteria shall be applied to determine their eligibility for that reproduction. ${ }^{68}$ Once again, a strong similarity of the requirements for protection can be traced to the Software Directive. This intention was confirmed by the EC which underlined the similar creative processes at the basis of databases and computer programs. Moreover, the European Commission stressed that computer programs are an essential component in database management. ${ }^{69}$

Furthermore, an important aspect of the Database Directive is the double-tier protection system that it creates. In addition to the copyright, the directive creates a sui generis form of protection for substantial investments in the obtaining, verifications and presentation of a database. This form of protection is different and autonomous from the one based on copyright and does not require any originality.

Significantly, it must be noted that the two forms of protection operate independently from each other and can be both present for the same database. The crucial aspect is that they protect two totally different goods: originality in the selection or arrangement of the database in the case of copyright; the substantial investment in the obtaining, verification and presentation (but not creation!) of the data the sui generis right. ${ }^{70}$

62 See Proposal for a Council Directive harmonising the term of protection of copyright and certain related rights, COM( 92$) 33$ Final, part I n. 9.

63 See Benabou, 1997, at 385.

64 See van Eechoud, 2012, at 62.

65 For a general overview on the protection of photographies in international law see Gendrau, Nordermann \& Oesch 1999. See also Walter \& Von Lewinski, 2010, at 8.6.13, where, however, the Netherlands are erroneously indicated as being included in the Initial Proposal Explanatory Memorandum list of countries granting special protection to common photographs.

66 See Walter \& Von Lewinski, 2010, at 8.6.12.

67 See Bently \& Sharman, 2014, at 115.

68 See Art. 3 Database Directive.

69 See Walter \& Von Lewinski, 2010, at 9.3.7

70 See Hugenholtz \& Davison, 2005, at 113-118; Hugenholtz, 2005; Margoni T., Guibault L. et al., Possible Forms of Legal Protection, in Guibault \& Wiebe, 2013. 


\subsection{2) The ECJ and the "horizontal" expansion of the originality standard}

Between 2009 and 2012, in five landmark decisions (Infopaq, BSA, FAPL, Painer and Football Dataco $v$ Yahoo $^{71}$ ) the ECJ took the opportunity to elaborate on the precise contours of the EU originality standard, which can be summarized as follows:

1) Under EU copyright law the required originality standard is the "author's own intellectual creation". This standard applies horizontally to all subject matter covered by EU copyright directives. $^{72}$

2) The author's own intellectual creation is present when authors can exercise free and creative choices and put their personal stamp in the work. ${ }^{73}$

3) When an expression is determined by technical or functional rules, such as when there is only one way to express an idea, or the expression is predetermined by a specific goal or constrained by narrow rules which leave no space to free and creative choices no originality can be present. ${ }^{74}$

Additionally, a fourth point can be inferred from these cases. Whereas the evocative wording employed by the Court could suggest that the AOIC requirement is particularly high, a closer look at the facts decided may indicate a different outcome. The ECJ recognised protection - or at least held that "it could not be excluded" - to an 11 word extract ${ }^{75}$, to a portrait photograph ${ }^{76}$, to a

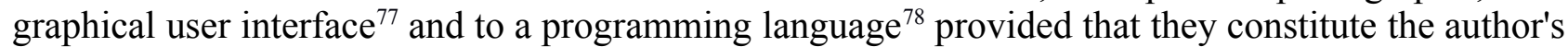
own intellectual creation -something for national courts to be determined. Match fixtures ${ }^{79}$ and sports games ${ }^{80}$ were nonetheless excluded from protection due to the lack of free and creative choices.

Consequently, it may be argued that the new standard created by the Court gives much more emphasis to the qualitative rather than the quantitative type of authorial contributions. ${ }^{81}$ Accordingly, a fourth point may be formulated:

4) It suffices to reach the required level of originality that authors make some free and creative choices and therewith put their personal stamp onto the work. However, skill and labour, even in

71 Case C 5/08 Infopaq International [2009] (Infopaq); Case C 393/09 Bezpečnostní softwarová asociace [2010] (BSA); Joined Cases C 403/08 and C 429/08 Football Association Premier League and Others [2011] (FAPL); Case C 145/10 Painer [2011] (Painer); and Case C 604/10 Football Dataco v Yahoo [2012] (Football Dataco v Yahoo). Other two important decisions are: Case C-168/09 Flos $v$ Semeraro [2011] (Flos) which expands the author's own intellectual creation to copyright protection of unregistered designs, whereas, for registered designs the situation is not yet clear; See Bently, 2012; and Case C 406/10 SAS Institute $v$ World Programming [2012] (SAS) which states that programming languages and data file formats can be protected as works - other than a computer program - if they are the author's own intellectual creation.

72 See Infopaq, at 36.

73 See Football Dataco v Yahoo, at 38; Infopaq, at 45; BSA, at 50; and Painer, at 89 and 92.

74 See FAPL, at 98; BSA, at 49; and Football Dataco v Yahoo, at 39.

75 See Infopaq.

76 See Painer.

77 See $B S A$.

78 See $S A S$.

79 See Football Dataco.

80 See FAPL.

81 Similarly, identifying the specific areas where the new EU standard and the "old" British one overlap and where they differ, see Bently \& Sherman 2014, at 102. 
significant amounts, are not conducive to these free and creative choices and therefore do not lead to the creation of a work possessing the required originality. ${ }^{82}$

In Infopaq, the first ground-breaking decision of the ECJ in the originality "saga", the Court underlined that it is apparent from the general scheme of the Berne Convention, in particular Article 2(5) and 2(8), that the protection of such certain subject matter as artistic or literary works presupposes that they are intellectual creations. ${ }^{83}$ Similarly, other works (i.e. computer programs, databases and photographs) are protected by copyright only if they are original in the sense that they are their author's own intellectual creation. ${ }^{84}$ The ECJ further stressed that, in establishing a harmonised legal framework for copyright, the Infosoc Directive is based on the same principle, as evidenced by Recitals 4, 9 to 11 and 20 in the preamble thereof. ${ }^{85}$ In accordance to the Court's ruling, copyright within the meaning of Art. 2(a) of the Infosoc Directive is liable to apply only in relation to a subject matter which is original in the sense that it is its author's own intellectual creation. ${ }^{86}$

These words, successively confirmed in the other decisions under analysis, represent the crucial transition from a partially harmonised to a fully harmonised standard of originality. ${ }^{87}$

The extent to which the fully harmonised level of originality covers the field of industrial design is not yet completely clear. In Case C-168/09 Flos v Semeraro, the ECJ was asked to determine whether a moratorium in respect of copyright protection for industrial design was compatible with Art. 17 and 19 of Directive 98/71/EC on the protection of Designs. While the Court's ruled against such compatibility, another aspect is relevant for the case of originality, one that attracted less attention than what might have deserved. ${ }^{88}$

At paragraph 34 the Court states:

"However, it is conceivable that copyright protection for works which may be unregistered designs could arise under other directives concerning copyright, in particular Directive 2001/29, if the conditions for that directive's application are met, a matter which falls to be determined by the national court".

The reasons why the European Court of Justice chose to take explicit position on this matter, which goes beyond what the referring court asked, are not entirely clear. A possible explanation is that in paragraph 34 the Court operated an additional extension of the concept of the author's own intellectual creation doctrine and covered the field of industrial design. This view seems supported by the Opinion of AG Jääskinen in Case C-5/11, even though the relevant passages were not carried over into the Court's judgement. ${ }^{89}$

82 See Football Dataco v Yahoo, at 53 (1) "the significant labour and skill required for setting up that database cannot as such justify such a protection if they do not express any originality in the selection or arrangement of the data which that database contains".

See Infopaq, at 34. Arts. 2(5) and 2(8) of the Berne Convention respectively deal with collections of literary or artistic works which constitutes 'intellectual creations' and with news of the day having the character or mere items of press information.

84 Id., at 35 .

85 Id., at 36.

86 Id., at 37.

87 See Cornish, Llewelyn \& Aplin, 2013, at 11.10.

88 Except for the already extensively cited Bently, 2012; See also Griffiths, 2013; Derclaye, 2014; Koenraad, 2013.

89 See Case C-5/11 Criminal proceedings against Titus Alexander Jochen Donner, at $27-31$. For a detailed analysis of the decision and for an explanation of its possible implications see Bently, 2012. 
Two major obstacles to the conclusion of a full harmonisation of the originality standard in industrial design should however be considered: Firstly, the plain meaning of Art. 17 of the Design Directive and of Art. 96 of the Design Regulation (the Regulation is not considered in the Flos case, however), which allow Member States to determine the extent to which, and the conditions under which, such a protection is conferred, explicitly including the level of originality required.$^{90}$ This approach seems supported, e.g. by the decision of the Supreme Court of Norway in the Tripp-Trapp case. $^{91}$

Secondly, the distinction between registered and unregistered designs, and in particular the fact that the Directive only harmonises the protection of national registered design, and not of national unregistered, Community registered and Community unregistered designs. Accepting an harmonised concept of originality for unregistered designs, would ostensibly create two different thresholds of originality depending on whether the design is registered or not and where (community v. national?), a contradiction aggravated by the fact that an unregistered community design can be registered during the one year grace period.

In conclusion, and putting the issue of industrial design aside for the moment, the newly defined level of originality can be said to be placed in between the high standard expressed in the past by some national courts (e.g. Germany), at least in relation to certain subject matter such as software, and the low standard sometimes provided by UK courts ("sweat of the brow"). This reading seems in line with the legislative history of the Directives that vertically harmonised the requirement of originality. ${ }^{92}$

An aspect worth noting, however, is the view expressed by AG Mengozzi in its opinion in Football Dataco v. Yahoo, in which he pointed out that the expression author's own intellectual creation "echoes a formula which is typical of the continental copyright tradition". This seems to contradict the legislative history exposed above, which documented that the AOIC expression - at least in the original formulation drafted for computer programs - was a compromise standard, that, if closer to any tradition, it would be to that of common law rather than civil law countries. ${ }^{93}$ If the statement of the AG is correct, it should be logically inferred that the ECJ did not only expand the concept of AOIC beyond the three vertically harmonised subject matter. ${ }^{94}$ The ECJ also modified the ambit of application of AOIC as originally conceived and moved it closer to the continental formula, in spite of its original construction. ${ }^{95}$

\subsection{3) The effects of AOIC on Member State domestic laws}

The effects of the ECJ author's own intellectual creation doctrine on national courts and standards have only recently started to unfold. Certainly, the new EU standard is unique and pervasive in the sense that no other tests are allowed under domestic laws. However, it will be a matter for national courts to establish whether a specific work meets the AOIC definition. In so doing it is safe to

\footnotetext{
$90 \quad$ See in general Margoni, 2013.

91 See Supreme Court of Norway, 27 June 2012, n. HR-2012-01325-A, (case no. 2011/2020) [Tripp-Trapp case].

92 See Green Paper on Copyright and the Challenge of Technology - Copyright Issues Requiring Immediate Action, COM (88) 172 final, at 5.6.4.

93 See above fn 2.2.1.a)

94 Although the element of a "personal stamp of the author" was originally introduced by the EU legislature in the Term Directive.

95 For a recent analysis of the ECJ jurisprudence on originality see Derclaye 2014, at 718; Griffiths 2013.
} 
assume that courts will be guided - consciously or unconsciously - by their own traditional legal constructions. Legal-cultural concepts are usually deeply rooted in the minds of law practitioners and interpreters and tend to survive, at least initially, legal or judicial reforms. ${ }^{96}$

That being said, one aspect can certainly be considered settled: the extent to which national legal systems recognised a different level of originality other than that attributed to software, databases and photographs is not compliant with Union law any longer. Currently, only one standard of originality applies to all subject matter covered by EU copyright law. There may be an exception connected to registered designs on the basis of Arts. 17 and 96 of respectively the Design Directive $^{97}$ and the Design Regulation ${ }^{98}$, but, as seen above, the relationship of these exceptions with the ECJ Flos decision is not yet settled..$^{99}$

Regarding the implementation of the AOIC standard by national courts, it is likely that most national courts will "import" the new ECJ test and, as far as they can, interpret it in a way that will correspond to their own traditional standards. In some countries this is made particularly likely by an undeniable similarity in the definitions of originality. This is for example the case in Germany, where works are protected as long as they are the "personal intellectual creation of an author". Other cases of similarity, even if not so straightforward, can be seen in France and Italy where works are protected if they are oeuvres de l'esprit - underscoring therefore both the author's presence and the intellectual personal element - or if they are opere dell'ingegno di carattere creativo, underlying both the presence of a personal stamp and of an intellectual creation.

Yet, it is clear that it is not at the terminological level that the issue will be solved, but at the interpretative one. Under this perspective, UK courts have already had occasion to state that the new ECJ standard restates, but does not substantially change the legal situation. ${ }^{100}$

Likewise, the Dutch Supreme Court held that the new EU standard is in line with the one commonly employed by courts in the Netherlands ${ }^{101}$ and the Dutch government repealed the part of the Dutch Copyright Act that granted protection to non original writings, precisely as a consequence of the Football Dataco v. Yahoo decision. ${ }^{102}$

In a 2013 case, the Supreme Court of Belgium confirmed that in light of the ECJ case law and in particular of Painer a work - specifically a fireplace design - is original if it is the intellectual creation of the author bearing his personal stamp. ${ }^{103}$ This ruling reversed a previous decision of the same Court holding that the "personal stamp" element was not required under Belgian law. ${ }^{104}$

In conclusion, it is likely that when courts start consistently implementing the new AOIC standard they will still argue that a given work was the result of free and creative choices on the basis of their traditional categories to the extent that this is still possible. Beyond this limit courts (or legislatures)

\footnotetext{
96 See in general Rouland, 1994.

97 Directive 98/71/EC of the European Parliament and of the Council of 13 October 1998 on the legal protection of designs.

98 Council Regulation (EC) No 6/2002 of 12 December 2001 on Community designs.

99 See Case C 168/09 Flos SpA v Semeraro Casa e Famiglia SpA [2011] (Flos); Opinion of the Advocate General in Case C-5/11 (Criminal proceedings against Titus Alexander Jochen Donner), of 2012, at fn 14; See L. Bently, 2012.

100 However "the full implications of the decision have not yet been worked out"; see NLA v Meltwater [2010] EWHC 3099 (Ch) at 81 (aff'd [2011] EWCA Civ 890).

101 See Supreme Court 23 February 2013 ( Stokke/H3 Products) para. 4.2.

102 See Beunen A.,Geschriftenbescherming: The Dutch Protection for Non-original Writings, in Hugenholtz B., Quaedvlieg A., Visser D., 2012.

103 See Supreme Court of Belgium, 31 October 2013, n. C.12.0263.N/1 [M-Design Benelux SPRL].

104 See Supreme Court of Belgium, 26 January 2012, n. C.11.0108.N [Artessuto case].
} 
will probably need to abandon the old standard. Nevertheless, where to draw the line will likely be the object of a fair amount of national court decisions in the years to come.

\section{Derivative works}

Derivative works (e.g. translations, adaptations and other alterations) have received more explicit attention in international conventions than the concept of originality. An example of this attention can be seen, for instance, in the Berne Convention where a few Articles indicate that some works, although based on other works, deserve autonomous (yet derivative) protection. At the EU level, a recently decided case may have revamped the interest on derivative works and on the harmonisation of the right to create adaptations.

\subsection{The international landscape}

The expression derivative works refers to those works that are based on pre-existing works. From this point of view derivative works are not "primary" works, such as those listed in Art. 2(1) BC, but "secondary". ${ }^{105}$ Derivative works possess therefore the potential of being a copyright infringement inasmuch as they require the adaptation, transformation, alteration, or translation of pre-existing works. ${ }^{106}$

Accordingly, when the Berne Convention states that

"Translations, adaptations, arrangements of music and other alterations of a literary or artistic work shall be protected as original works without prejudice to the copyright in the original work"107

it employs the adjective original in two completely different ways. The first "original" refers to the concept of "intellectual creations" discussed in Sec. 2 above, whereas the second "original" refers to the fact that the work is not based on a pre-existing work. Consequently, the latter "original" refers to "primary" works - listed in Art. 2(1) BC - and has to be read in juxtaposition to "derivative" works that are based on pre-existing ones. ${ }^{108}$

When the transformation, adaptation or alteration is sufficiently original as to constitute an "intellectual creation" in its own right, the protection afforded to derivative works is assimilated to that afforded to original works by Art. 2(1) BC. Nevertheless, this is without prejudice to the copyright in the pre-existing work. Therefore, the authorisation of the right holder is necessary to avoid liability for copyright infringement, unless the use is covered by a specific exemption or the pre-existing work has fallen into the public domain. If the derivative work is created in absence of authorization or outside the cases admitted by law, and constitutes therefore an unauthorized use, it

105 See Ricketson \& Ginsburg, 2006, at 8.75.

106 Art. 10 of the text discussed at the Diplomatic Conference of 1884 treated musical compositions as a form of infringement. The modern wording of art 2(3) can be traced back to the text approved during the Berlin Act of 1905; See Ricketson \& Ginsburg, 2006, at 8.77 .

107 See Art. 2(3) BC.

108 Id. 
generally still attracts protection. ${ }^{109}$ The U.S., however, have a specific provision whereby a derivative work unlawfully created does not benefit from copyright. ${ }^{110}$

Evidently, not every case of creation of a work based on another work constitutes an act of adaptation or alteration requiring authorization. In order to constitute a derivative work the elements constituting the intellectual creation in a primary work need to be reproduced, adapted or altered in the secondary work. Consequently, if a work is only inspired by the idea expressed in a previous work, there is simply no act of derivation and accordingly no authorization is required. In these cases, the resulting work, if an intellectual creation in its own right, is protected as an original (primary) work.

Three cases of derivative works are specifically regulated by the Berne Convention: translations, arrangements of music, and adaptations and other alterations.

Translations commonly refer to changing a literary or dramatic work from one language into another. ${ }^{111}$ Whether the term language includes only "traditional" human languages, or, on the other hand, includes also modern forms of "artificial" languages such as computer programming languages is ultimately a matter to be decided by domestic law, but in principle not incompatible with Berne's broad definition. ${ }^{112}$

Arrangements of music generally involve skills such as adaptation and transcription of a musical part for one instrument into that for another, or the addition of rhythmic parts to a melody. ${ }^{113}$

The third category, adaptations and other alterations, constitutes a residual class whose scope is to cover all the elaborations "considered to fall within the scope of adaptation" such as "dramatizations and choreographic or mime adaptations, the making of prose versions of dramatic works, the rendition of a literary or dramatic work into a dramatic-musical form and so on". ${ }^{114}$

These open ended definitions, however, encounter a precise limit. Only the adaptations and alterations that involve new authorial contributions can benefit from the assimilation of the protection afforded to original works. Omissions or changes of small sections and the incorporation of other material not accompanied by new original additions are not not included in the protection as derivative works. ${ }^{115}$

Furthermore, it must be noted that translations, adaptations and other alterations not only constitute protectable subject matter in their own right as established by Art. 2(3). The Convention explicitly recognises to authors of literary or artistic works the enjoyment of the exclusive right of authorizing adaptations, arrangements and other alterations of their works (Art. 12) and that authors of literary and artistic works shall enjoy the making and authorising of the translation of their works throughout the term of protection of the original works (Art. 8). Moreover, authors of dramatic, dramatic-musical and literary works enjoy, during the full term of their rights in the original works, the rights of authorizing the public performance/recitation and communication to the public of the translations of their works (Art. 11-2 and 11ter-2).

\footnotetext{
109 Goldstein \& Hugenholtz, 2013, at 6.1.2.7.

110 See U.S. Copyright Act 1976 Sec. 103(a)

111 Ricketson \& Ginsburg, 2010, at 8.78. Goldstein \& Hugenholtz, 2013, at 6.1.2.7.

112 Id.

113 Id., at 8.79.

114 Id., at 8.81; Masouyé C., 1978, at 76-7.

115 Goldstein \& Hugenholtz, 2013, at 8.81.
} 
Finally, authors of literary or artistic works have the exclusive right of authorizing the cinematographic adaptation and reproduction of their works, and the distribution, public performance and communication to the public of the works so adapted or reproduced. The adaptation into any other artistic form of a cinematographic production derived from literary or artistic works shall, without prejudice to the right in the cinematographic production, remain subject to the authorization of the authors of the original works (Art. 14).

\subsection{The European Acquis Communautaire}

As seen above, many of the EU directives in the field of copyright regulate rights of economic exploitation such as the reproduction right, the distribution right and the right of communication to the public. Traditionally, this was done through a "vertical" approach such as in the case of the Software and Database directives. The Infosoc Directive took for the first time a broad horizontal approach and offered a generous definition of the right of reproduction, communication to the public and distribution.

However, the adaptation right has usually remained untouched by these vertical and horizontal harmonising interventions. Unique exceptions to this lack of regulation are found in the Software and in the Database Directives where both adaptations and translations are explicitly mentioned. ${ }^{116}$

\subsubsection{The Software and Database Directives}

Recital 15 of the Software Directive states that translations, adaptations or transformations of the form of the computer program code constitute an infringement of the exclusive rights of the author, unless these acts are necessary to achieve interoperability. Preparatory design materials are also protected, since all subsequent programming steps can be considered adaptations of the preceding stages. ${ }^{117}$ Furthermore, Art. 4(b) states that the rights vested in the author of a computer program include the translation, adaptation, arrangement and any other alteration of a computer program, subject to the exceptions listed in Arts. 5 and $6 .{ }^{118}$

Regarding the Database Directive, Art. 5(b) establishes that in respect of the expression of the database which is protectable by copyright, the author has the exclusive right to translate, adapt, arrange and perform any other alteration. It must be noted that Art. 5 deals with copyright protection and therefore translations and adaptations refer to the selection or arrangement of the database and not to the data. It has been stated that the translation of the structure of a database is "hardly imaginable". ${ }^{119}$

\footnotetext{
116 See Art. 4(1)(b) Software Directive and Art. 5(b) Database Directive.

117 Walter \& von Lewinski, 2010, at 5.1.39

118 See Recital 15 and Art. 4 of the Software Directive; Walter \& von Lewinski, 2010, at 5.1.39; Samuelson, Vinje \& Cornish, 2012.

119 See Walter \& von Lewinski, 2010, at 9.5.9.
} 
It follows that, from a EU perspective - and with the exception of software and databases translations, adaptations and transformations of works into new expressive forms are left to MS discretion. The reasons for such a gap in the full harmonization of the rights of economic exploitation can be attributed to the "borderline" nature of the right of adaptation. The adaptation of a work often requires its, at least partial, reproduction. Yet, there is more: as seen above, a simple reproduction of a work accompanied by small non-creative modifications, does not lead to the creation of a derivative. A derivative work requires an authorial original contribution of the intervening author; however, until recently the concept of originality was not harmonised. Hence, a proper harmonization of the adaptation right without simultaneously harmonising the threshold of originality could have caused unpredictable consequences. ${ }^{120}$

\subsubsection{Adaptations and integrity}

Moreover, derivative works and the economic right of authorising adaptations and modifications are intimately connected with the moral right of integrity. Moral rights, similarly to the concept of originality until 2009, are not object of harmonisation in EU law. As usual, a common reference can be found in Art. 6-bis of the Berne Convention which establishes that authors shall have the right to claim authorship of the work and to object to any distortion, mutilation or other modification of, or other derogatory action in relation to, the said work, which would be prejudicial to their honour or reputation. ${ }^{121}$ These rights are independent from the economic rights, shall remain with the author even after the transfer of the rights of economic exploitation and shall be maintained at least until the expiry of the economic rights. ${ }^{122}$ At the MS level additional moral rights may be recognised. Usually, the right of disclosure, the right of retract (or withdraw) and the right of access are commonly found in EU Member States. ${ }^{123}$

Of particular relevance for the present purpose is the second right recognised by the Art. 6-bis(1), also known as the right of integrity. The strong connection between the (economic) right that regulates the creation of adaptations and creative elaborations and the (moral) right that protects the integrity of the work is clear, as it is clear the potential conflict caused by the transferable nature of the former and the non transferable nature of the latter. ${ }^{124}$

In conclusion, it can be said that the absence of a harmonised right of adaptation was well justified by the concomitant absence of harmonisation of the originality requirement and of moral rights, in particular of the right of integrity. Such an absence was partially compensated by a broadly defined - and harmonised - right of reproduction. Whereas the latter does not explicitly include a right of adaptation, it must be also noted that at the MS level some Copyright Acts systematically classify the right of adaptation as a form of reproduction. ${ }^{125}$

\footnotetext{
120 See van Eechoud, Hugenholtz, van Gompel, Guibault, Helberger, 2012, at 84.

121 See in general Goldstein 1983. The honour and reputation requirement is set in the Berne Convention. Some MS state however do not explicitly include the harm to the honour and reputation as a requirement; see Salokannel \& Strowel, 2000, at 16.

122 See Art. 6-bis Berne Convention.

123 See Salokannel \& Strowel, 2000.

124 Moral rights are usually non transferrable but they can be waived in many jurisdictions.

125 See van Eechoud, Hugenholtz, van Gompel, Guibault, Helberger, 2012, at 84.
} 


\subsubsection{The Court of Justice and the European Commission on the right of adaptation}

As seen above, starting in 2009 the first of these two justifications started to fade away and currently it can be affirmed that the concept of originality is completely harmonised at the EU level. The same, however, does not hold true for moral rights. As the ECJ has recently confirmed, moral rights are a matter of MS law (as clearly stated in i.a. Recital 19 of the Infosoc Directive) and must be exercised in compliance with the provisions of the Berne Convention, the WCT and the WPPT. ${ }^{126}$ Nevertheless, by stressing the importance of the function of parody under EU law and in particular its relationship with the right of freedom of expression, the Court seemed to imply that there are EU related limits to moral rights protection. ${ }^{127}$

Whether these two recent events point to the fact that the right of adaptation will soon be, or perhaps has already been at least in part, harmonised is not clear. The best opinion, in absence of an explicit legislative intervention is that the right of adaptation has to date not been object of EU harmonisation. ${ }^{128}$

Nevertheless, the European Commission appears to have recently expressed a different view. In an unofficial draft document, and therefore with all the cautions due in similar cases in relation to the correctness of the view therein expressed, the EC purports the idea that the adaptation right might in fact have been object of EU harmonisation. ${ }^{129}$ Discussing the issue of User Generated Content, the EC recognised that "contrary to the reproduction right and communication to the public/making available right, there is no express rule with respect to adaptations in the Infosoc Directive". The Document continues and opines that "the broad manner in which the reproduction right in Art. 2 is formulated and the CJEU's jurisprudence on the scope of the reproduction right notably in Infopaq and Eva-Maria Painer seem to cover adaptations which give rise to a further reproduction within the meaning of Art. 2". ${ }^{130}$

Opportunely, the EC leaves the door open to possible different interpretations, making explicit reference to the aforementioned case - at the time of the leaked document - pending before the ECJ, which has now been decided (as of January 2015). ${ }^{131}$ All the same, it should be also noted that the EC intervened in that case and supported the broad interpretation of the right of reproduction. ${ }^{132}$

126 See Opinion of the AG Pedro Cruz Villalón of 22 May 2014 in Case C-201/13 (Deckmyn v Vandersteen), at 4 and 28.

127 In the following decision (Case C-201/13) the ECJ offered its interpretation of what constitutes a parody under EU law stressing the strict relation it possesses with the fundamental right of freedom of expression and identifying the multiple implications of the use of modified version of a work for transformative purposes such as parody. The Court, or more correctly the AG, also clarified that the decision could not address the issue of moral rights. At the national level, see for example the decision of the Brussels Court of Appeal of 8 June 1978 (Tin-Tin and Suisse, rejecting the parody defence), cited in Salokannel \& Strowel, 2000; Court of Appeal of Amsterdam of 13 September 2011 BS 7825 in favour of parody for the use of Nijntje).

Only the AG opinion expressly dealt with the issue of moral rights, the Court did not mention them in its decision.

129

The document is the Commission's draft Impact Assessment on the modernisation of the EU acquis made originally available on the Statewatch website. The specialised IP blog "The IPKat" gives a detailed account here http://ipkitten.blogspot.co.uk/2014/04/breaking-news-draft-impact-assessment.html.

130 See draft Impact Assessment, at 99.

131 Id.

132 See infra fn 131. 


\section{a) Allposter v Stichting Pictoright}

The recently decided case is Allposter $v$ Stichting Pictoright a reference from the Dutch Supreme Court (Hoge Raad) examining the transfer of images of paintings from posters to canvas. The Hoge Raad referred four questions to the ECJ. It asked: 1) to define the scope of Art. 4 Infosoc directive (i.e. distribution right) and whether it includes a right to distribute modified copies; $2 \mathrm{a}$ ) whether the fact that the redistribution happens in modified form has any consequence on Art. 4(2) regulating the exhaustion of the right of distribution; $2 b$ ) which type of modifications can avoid the exhaustion of the distribution right; and finally 2c) whether a national rule, such as the Dutch, which excludes exhaustion when the reseller modifies the work and then distributes it (Poortvleet doctrine), is allowed under EU law. ${ }^{133}$ Or, as the AG Cruz Villalón summarised in its Opinion "Can the right holder of a pictorial work, who authorised the sale of posters based on that work, prevent the commercialisation of the same images transferred on canvas"? ${ }^{134}$ The ECJ borrowed the AG reformulation of the referred questions and re-proposed it in a slightly more articulated form. ${ }^{135}$

As the AG clarifies in pars. $51-53$, the question asked by the referring Court is limited to the right of distribution and does not consider the right of reproduction. Consequently - the AG continues even though the question could be relevant in terms of the right of reproduction (and its relationship with the right of adaptation) his opinion will disregard that right and only focuses on the right of distribution. This is at the same time comprehensible and disappointing, since one of the most interesting questions related to the case and elaborated to some extent by the intervening parties (the French Government, the British Government and the EC) could have been avoided.

The Court, however, apparently realised the logical impossibility to solve the referred questions without addressing, at least in part, the issue of the adaptation right and its relation to the right of reproduction. Accordingly, the Court confirmed that Article 12 of the Berne Convention confers on authors of literary and artistic works an exclusive right of authorising adaptations, arrangements and other alterations of their works and that there is no equivalent right in the Infosoc Directive. ${ }^{136}$

Nevertheless, the Court held that - without having to interpret the concept of "adaptation" within the meaning of Berne, an exercise found in the AG Opinion - it suffices to state that both the paper poster and the canvas transfer contain the image of a protected artistic work and thus fall within the scope of the right of reproduction (Art. 4 Infosoc). ${ }^{137}$

That being said, it is noteworthy for present purposes to briefly look at the qualification of the right of adaptation present in the words of the AG in the remainder of its Opinion:

"... one of the essential elements of "adaptation" as a process of adjustment of the
subject matter of an artistic creation to the methods of expression peculiar to
different types of art lies in the diversity of languages and artistic techniques.
Another of its essential elements concerns adaptation as a technique of creative
expression which seeks to intervene in the work itself rather than to adjust the work

\footnotetext{
133 See Case C-419/13, of 22 January 2015 Art \& Allposters International BV v Stichting Pictoright, (Allposters).

134 See Opinion of the Advocate General Pedro Cruz Villalón of 11 September 2014 in Case C-419/13 Allposters.

135 “... the questions referred, which should be considered together, must be understood to mean that the referring court is asking, in essence, whether the rule of exhaustion of the distribution right set out in Article 4(2) of Directive 2001/29 applies in a situation where a reproduction of a protected work, after having been marketed in the European Union with the copyright holder's consent, has undergone an alteration of its medium, such as the transfer of that reproduction from a paper poster onto a canvas, and is placed on the market again in its new form", See Case C-419/13 (Allposters), at 23.

137 Id., at $27-28$.
} 
to the expressive characteristics of another artistic language, making the work, in its own language, a different work in so far as it is only vaguely recognisable in its original expression" 138

On the basis of this formulation of the adaptation right the AG concludes that the facts at issue in the main proceedings do not constitute an adaptation, since there is no different artistic language nor there are additions or modifications to the creative expression. In the present case - the AG states the objective of the elaboration is to reach the highest possible grade of identity with the original. ${ }^{139}$

The Court, avoiding to enter into an analysis of the right of adaptation, substantially followed the AG Opinion on this point. In particular, with regard to the transfer of the image from poster to canvas, the Court noted that such a replacement of the medium results in the creation of a new object incorporating the image of the protected work, whereas the poster itself ceases to exist. ${ }^{140}$ Such an alteration of the copy of the protected work, which provides a result closer to the original, is actually sufficient to constitute a new reproduction of that work, within the meaning of Article 2(a) Infosoc, which is covered by the exclusive right of the author and requires his authorisation. ${ }^{141}$

Crucially, the Court rejects the Allposters's argument that no act of reproduction is performed, since there is no multiplication of copies of the protected work (the transfer of the ink from the poster to the canvas not only reproduces the image on the new medium, but erases it from the old one). ${ }^{142}$

\begin{abstract}
"The fact that the ink is saved during the transfer cannot affect the finding that the image's medium has been altered. What is important is whether the altered object itself, taken as a whole, is, physically, the object that was placed onto the market with the consent of the right-holder. That does not appear to be the case in the dispute in the main proceedings "143
\end{abstract}

Consequently, the Court concludes that the consent of the copyright holder does not cover the distribution of an object incorporating his work if that object has been altered after its initial marketing in such a way that it constitutes a new reproduction of that work. ${ }^{144}$

\title{
3.3 Some final considerations on the right of adaptation
}

The Court clearly established that, differently from the right of reproduction and the right of distribution, the right of adaptation is not present in the European aquis. ${ }^{145}$ The Court, however, also stated that certain kind of alterations, such as the one at stake in the main proceedings, are covered by the harmonised right of reproduction. ${ }^{146}$ The question that the Court did not address is how to

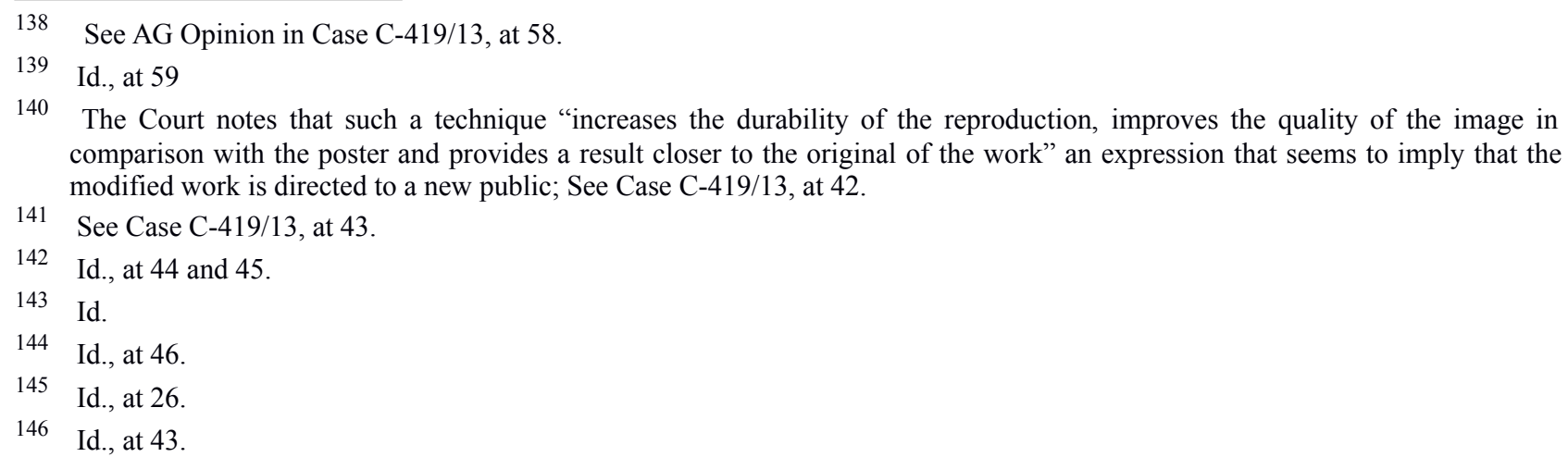


distinguish between non harmonised adaptations and alterations included in the right of reproduction.

In accordance to previous ECJ case law, a reproduction, in order to be covered by Art. 2 of the Infosoc directive - i.e. reproduction by any means and in any form, in whole or in part - needs to reproduce the author's own intellectual creation. The ECJ clearly stated that even a small or short reproduction - such as 11 words - can constitute an infringement of the reproduction right provided that the short reproduced strings constitute the author's own intellectual creation. ${ }^{147}$ The facts under analysis in Allposter related to a perfect reproduction of the original image onto the new medium, and therefore the reproduction certainly included the author's own intellectual creation present in the original.

Consequently the question is: Does the same infringement test apply also to the right of adaptation? Admittedly, a mere extension of the Infopaq infringement test to the right of adaptation will lead to the assimilation of the latter into the already broadly defined right of reproduction. Nonetheless, a similar course of action would deny the idiosyncrasy of a right to create derivative works. This speciality resides in the fundamentally different normative function carried out by the right to create adaptations. This function is to delimit the boundaries between infringing activities and permitted uses and basically defines the scope of copyright in modern legal systems. ${ }^{148}$ In particular, in knowledge-based and digitally enhanced societies this function is fundamentally connected to the role that transformative uses possess. More and more, the creation of new forms of expression employing existing works - very often to an extent that certainly satisfies the Infopaq test constitutes a central element of new social and economic practices, particularly in on-line environments. This can be seen, for instance, in phenomena such as User Generated Content (UGC), Text and Data Mining (TDM), and the digitisation of cultural heritage. The more transformative a work is, the less likely a finding of infringement should be, irrespective of how much of the original author's own intellectual creation has been taken.

Conversely, a rigid test that only looks at the amount taken, therefore reducing the right of adaptation to a particular form of reproduction, would deny the added cultural, social and economic value that the concept of transformative uses embraces. Likewise, such a rigid test would also stifle transformative uses that constitute manifestations of the freedom of expression (e.g. chilling effect) of transformative users.

In conclusion, a flexible test the compares the amount reproduced with the added creative elements and evaluates how distant is the final transformative use from the original work would certainly strike a fair balance between creativity, innovation and freedom of expression. ${ }^{149}$ Furthermore, it must be reiterated that if it is accepted that the concept of adaptation is ontologically different from that of reproduction, as it is here suggested, then a broad exception for the case of transformative works, that is to say an exception to the right of adaptation, would not be limited by the closed list of art. 5 Infosoc. ${ }^{150}$

\footnotetext{
147 See Infopaq, at 39.

148 In this sense Gervais, 2013.

149 The U.S. fair use doctrine is certainly an inspiring model.

150 See van Eechoud \& all, 2012, 84; Hugenholtz \& Senftleben, 2011. In the same sense a Gervais, 2013. See also the Report prepared by the Irish Copyright Review Committee, Modernising Copyright, Dublin 2013, at 55 and 72 (available at http://www.enterprise.gov.ie/en/News/2013/October/-Copyright-report-published-aimed-at-supporting-digital-industry\% $2 \% 80 \% 93-$ Minister-Bruton.html
} 


\section{Photographic works and non original photographs}

This part briefly outlines the international and EU protection afforded to photographic works. The protection offered by EU law to photographs, at least in terms of originality, has already been discussed supra in the chapter dedicated to "originality" and will therefore not be repeated. Some elements connected with the ECJ analysis of the protection of photographs (i.e. Painer) are concisely presented. Additional elements of analysis regarding the implementation of EU legislation, the special case of "other photographs" and MS case law are present below in part II.

\subsection{The international landscape}

When photography was invented at the beginning of the $19^{\text {th }}$ century, it was seen as a mechanical process where the opportunity to express one's creativity was denied by an extremely rudimentary (for today's eyes) technique. ${ }^{151}$ During the nineteenth century and the beginning of the twentieth, however, photography became more sophisticated and allowed operators to regulate and modify a number of parameter in order to obtain better results. These possibilities, that is to say, the choices that photographers could make in order to obtain the desired results came to be seen as creative and therefore the idea that photography could be conceived as a form of art deserving copyright protection began to spread. ${ }^{152}$

Photographic works have been included in the enumeration of works of Art. 2(1) of the Berne Convention only in the Brussels revision of 1948, yet they were recognised as copyright subject matter in many countries since much longer. Other countries, however, refused to recognise creativity to acts that were deemed to involve technical skills rather than creativity. ${ }^{153}$ As it is reported by Ricketson, the tension between these two opposed approaches lead to the approval of a declaration in the Closing Protocol to the original Berne Act of the Convention of 1886:

As regards Article 4, it is agreed that those countries of the Union where the character for artistic works is not refused to photographs engage to admit them to the benefits of the Convention concluded today, from the date of its coming into force. They shall, however, not be bound to protect the authors of such works further than is permitted by their own legislation ... It is understood that an authorised photograph of a protected work of art shall enjoy legal protection in all countries of the Union, as contemplated by the Convention for the same period as the principal right of reproduction of the work itself subsists, and within the limits of private agreements between those who have legal rights.

Accordingly, as per the first version of the Berne Convention, the only photographs required to be protected by Union Members were authorised photographs of protected works of art. Regarding all

\footnotetext{
151 The earliest still surveying camera photograph, View from the Window at Le Gras, dates back to 1826; See https://en.wikipedia.org/wiki/View from the Window at_Le_Gras

152 See Bently \& Sherman, 2014, at 95; Bettink,1989, at 37; Deazley, 2010, at 293; Garnett, 2000; Gendreau, Nordemann \& Oesch, 1999; Hughes, 2011-2012.

153 To the first category of countries belong France and the UK, while to the second Germany; See Ricketson, International Conventions, in Gendrau, Nordemann, \& Oesch, 1999, at 18.
} 
other photographs, protection was left to the discretion of those Berne Countries which deemed photographs to be artistic works. ${ }^{154}$

The uniform recognition of photographic works and of their protection grew among Berne Countries as it can be read in the different revisions of the Convention. By 1908 photographic works and works obtained by an analogous process were recognised as a protected subject matter, even though they were not considered as literary and artistic works and there was no reference to the duration of the protection. ${ }^{155}$

As said, it was not until the Brussels revision of 1948 that photographs were recognised as a form of artistic work and were included in the list of Art. 2 generally protecting literary and artistic works. Yet, the full assimilation of photographs to other works of authorship never achieved its completion in Berne, at least in relation to the term of protection. Since the Stockholm revision of 1967 it was established a minimum of 25 years from the making of the photograph, a term that has not been modified in the text of the Berne Convention until today. ${ }^{156}$

Nevertheless, as it is well known, the term of protection of photographs for signatories of the WIPO Copyright Treaty of 1996 (which is considered as a special agreement within the meaning Art. 20 of the Berne Convention), is substituted with that of Art. 7(1) Berne Convention, that is to say, 50 years post mortem auctoris. ${ }^{157}$ For EU Member States, the Copyright Term Directive has extended the general term of protection for photographic works (i.e. those that are the author's own intellectual creation) to 70 years. ${ }^{158}$

The obligations established by Berne refer to photographic works, that is to say to intellectual creation expressed through photography or a process assimilated to it. As seen, the specific determination of the level of originality required is left to the discretion of the Berne Union members. The Berne convention itself, only requires the protection of photographic works, and does not regulate the protection that countries can afford to other types of photographs by way of neighbouring rights. ${ }^{159}$

\subsection{The European landscape}

As seen in chapter 2, discussing the level of originality in EU law, the Term Directive established that photographs which are original in the sense that they are the author's own intellectual creation reflecting his personality shall be protected by copyright and that no other criteria such as merit or purpose shall be taken into account to determine their eligibility for protection. ${ }^{160}$

In Painer the ECJ elaborated further the concept of author's own intellectual creation in relation to photographic works, and especially to portraits. The Court established that the photographer can make free and creative choices in several ways and at various points in the creation of a

\footnotetext{
154 See Ricketson in Gendrau et all, at 19.

155 Id., at 22.

156 See Art. 7(4) Berne Convention.

157 See Art. 9 WIPO Copyright Treaty.

158 Regarding the harmonisation of the term of protection of copyright in the EU see generally Angelopoulos 2012.

159 See Ricketson in Gendrau et al, at 25.

160 See Recital 16 and Art. 6 Directive 2006/116/EC (codified version).
} 
photographic work. ${ }^{161}$ The first identified moment is in the preparation phase, during which the photographer can choose the background, the subject's pose and the lighting. ${ }^{162}$ Secondly, when taking a photograph, he can choose the framing, the angle of view and the atmosphere created. ${ }^{163}$ Thirdly, when selecting the snapshot, the photographer may choose from a variety of developing techniques the one he wishes to adopt or, where appropriate, use computer software. ${ }^{164}$ By making those various choices, the author of a (portrait) photograph can stamp the work created with his "personal touch". ${ }^{165}$

On this basis, the Court concludes that a specific type of photograph, a portrait photograph, cannot be excluded from protection by the sole fact that the choices available are too limited when the photographed object or subject are predetermined. Nevertheless, it will be a matter for national courts to determine whether any specific picture possess the author's personal stamp.

Not only photographs are recognised as protectable subject matter by the Term Directive. As seen, the last part of Art. 6 allows MS to afford protection to "other photographs". In general terms, the protection that some MS recognise to "other photographs" is defined negatively, that is to say by offering protection to photographs that do not qualify as works of photography. European countries recognising this form of protection (7 EU members plus 2 EEA members ${ }^{166}$ ) usually accord rights similar to that of regular copyright (however there are significant exceptions) for a period of time that is considerably shorter. The term of protection is probably the most inhomogeneous aspect across countries and varies from 15 to 50 years from production or publication. ${ }^{167}$ Regarding the subjective element, i.e. what type of human input is requested, it is certainly below the now harmonised level of originality (the author's own intellectual creation). Yet, there need to be "something", a minimum element of craftsmanship, intellectual input or photographic activity involved. This minimum amount is necessary to "draw the line of demarcation between photography on the one hand and mere copying on the other" and is left to the discretion of MS. ${ }^{168}$

In conclusion, the Copyright Term Directive established two main principles in relation to photography: it harmonised the originality standard for photographic works and allowed MS to grant protection to "other" photographs. In part II it will be analysed how this double system of protection, where present, operates.

\footnotetext{
161 See Painer, at 90.

162 Id., at 91.

163 Id.

164 Id.

165 Id., at 92. See for a comparison the U.S. Supreme Court case Burrow-Giles Lithographic v. Sarony, 111 U.S. 53 (1884).

166 Germany, Spain, Italy, Austria, Denmark, Finland, and Sweden, plus Iceland and Norway; see infra Table n. 2.

167 Norway however requires 15 years p.m.a., but at least 50 years from creation.

168 See Walter M., in Gendreau et al, 1999.
} 


\section{Part II - Country Overview}

\section{Germany}

\subsection{Originality}

The German Copyright Act (UrhG) ${ }^{169}$ protects literary, scientific and artistic works, among which it illustratively lists writings, speeches, musical works, works of fine art, works of photography, cinematographic works, and illustrations of a scientific or technical nature. ${ }^{170}$ The list is nonexhaustive and is followed by a general clause which defines copyright-protectable as all works that are "personal intellectual creations". ${ }^{171}$

In order to establish that a work is a personal intellectual creation four cumulative criteria are usually considered. According to these criteria a work is a "personal creation" (the work has to originate from a person) with an "intellectual content" (an idea that is expressed) in a "perceptible form" (the work need to be expressed in a form that can be perceived) which has a certain degree of "individuality" (the work has specific characteristics that make it original). ${ }^{172}$ This does not mean that works need to be novel or unique, but they need to be creative and individual to the author. ${ }^{173}$

Consequently, mere ideas are not protected and they need to be expressed or formalized in a specific form in order to enjoy protection. ${ }^{174}$ However, fixation is not a requirement and "live" works such as live television shows and live artistic performances find protection under German copyright law. ${ }^{175}$ The requirement of a formal expressive elaboration, however, should not be interpreted as a particularly high standard of originality, as confirmed, for instance, by the fact that trivial/minor literary works are usually protectable ("small change" or kleine Münze). ${ }^{176}$ Accordingly, catalogues, address books, single sentences and operating instructions have been found sufficiently original to deserve protection. ${ }^{177}$

\subsection{Derivative works}

\footnotetext{
169 German Copyright Act, Act of 9 September 1965 "Gesetz über Urheberrecht und verwandte Schutzrechte", UrhG.

170 See Arts. 1 and 2 German Copyright Act.

171 See Fromm \& Nordemann, 2008, at Sec. 2, para. 11.

172 See Dietz, Substantive Criteria, in Geller \& Bently, 2013, at 2[1][b]. Handig, 2013, at 336. Nordemann, in Gendrau, Nordemann \& Oesch, 1999, at 137.

173 Id

174 See Dietz, Substantive Criteria, in Geller \& Bently, 2013, at 2[1][b]. Handig, 2013, at 336., at 2[1][b].

175 See Case I-20 U 171/10 (Court of Appeal Dusseldorf) of 30.12.2011, in GRUR 2012, 173 (considering protectable a live art performance; amended, but not on this aspect by Case I ZR 28/12 (German Supreme Court, BGH) of 16.5.2013, in GRUR 2014, 65).

176 See Schricker, 1995, at 41.

177 See Dietz, Substantive Criteria, in Geller \& Bently, 2013, at 2[1][b]. Handig, 2013, at 336., at 2[1][b]; See Case No. I ZR 147/89 (German Supreme Court, BGH) of 10.10.1991, in IIC 1992, 846.
} 
Derivative works are protected by Art. 3 of German Copyright Act as long as they constitute a personal intellectual creation of the adaptor. ${ }^{178}$ Art. 3 specifically refers to translations (Übersetzungen) $)^{179}$ and other adaptations (andere Bearbeitungen), but it includes also other types of elaborations such as dramatizations, orchestrations, and new versions of works. ${ }^{180}$ However, insubstantial adaptations of unprotected musical works do not constitute protectable adaptations similarly to any other unoriginal contributions. ${ }^{181}$

In order to establish whether an adaptation infringes an original work the features that determine the original character of the primary work are decisive inasmuch as they determine the extent of the scope of protection. ${ }^{182}$ This seems to imply that works with a lower, but still sufficient, level of originality are less likely to be infringed as the scope of protection is allegedly narrower. ${ }^{183}$ Older authorities, though, propose a reading that requires the same level of originality for any derivative work, regardless on how original the primary work is. ${ }^{184}$

Art. 23 of the German Copyright Act establishes that adaptations or other transformations of a work may be published or exploited only with the consent of the author of the adapted or transformed work. Therefore, in cases such as cinematographic adaptations of novels, or translations of articles from one language into another, the original author's consent is required.

Nevertheless, German law explicitly provides for "free uses" of works in cases of adaptation. Art. 24 states that an independent work created by free use of the work of another person may be published and exploited without the consent of the author of the used work. ${ }^{185}$ Free use can be assumed if the adaptor only borrows minor parts of the original copyright protected work. What counts, in this sense, is the difference that the secondary work shows in relation to the unique features - the personal intellectual creation - of the adapted work. ${ }^{186}$ A "fair use" therefore requires that "the peculiar features borrowed from the protected pre-existing work fade into the background in the new work in such a manner that the new work no longer utilizes the pre-existing work to a relevant extent, with the result that the latter appears as nothing more than a stimulus toward the creation of a new, independent work". ${ }^{187}$

\footnotetext{
178 See Art. 3 UrhG.

179 See Case I ZR 57/97 of the German Federal Supreme Court (BGH) of 15.09.1999 [Comic-Übersetzungen II] (establishing that also translations of "simple dialogues", such as in the case of comics, are protected as they constitute the authors' personal intellectual creations).

See Dietz., Derivative works, new versions and compilations, in Geller \& Bently, 2013, at 2[3][a].

181 See Art. 3 UhrG.

182 See Decision Federal Supreme Court (Bundesgerichtshof) of July 8, 2004 - Case No. I ZR 25/02 "Dog Character" (Hundefigur).

183 Id.

184 See BGH 03.11.1967 Ib ZR 123/65 "Haselnuß", in GRUR 1968, 321.

185 This does not apply to the use of a musical work where a melody has been recognizably borrowed from the work and used as a basis for a new work, see Art. 24 UhrG.

186 See Case I ZR 264/91 (BGH) of 11.03.1993 [Asterix-Persiflagen] in IIC 1994, 610 [The Federal Supreme Court however also points out that "Nevertheless, fair use is not only to be assumed where the peculiar features borrowed from a protected, preexisting work fade in the new work in a more literal sense and accordingly recede therein in such a way that, in the newer work, the pre-existing work only shimmers through weakly and in a manner that is no longer relevant in terms of copyright law. If fair use were only possible in this manner, then any artistic use of still-protected works - whether in the form of a parody or any 187 other form - would be too narrowly restricted"]. Id.
} 


\subsection{Photographic works and non original photographs}

German law offers protection to original photographs as photographic works under the provision of Art. 2. It follows that in order to be considered a work of photography photographs need to constitute a personal intellectual creation of their author, a requirement that seems in line with the EU mandated standard. ${ }^{188}$

Furthermore, German law offers protection to non original photographs, a category that includes products manufactured employing techniques similar to photography. These photographs do not reach the personal intellectual creation standard of Art. 2, yet they are protected by the the German Copyright Act in an almost equivalent form, that is to say, by extending - as long as compatible the provisions protecting original photographs. ${ }^{189}$ Consequently, it is observable an almost perfect assimilation of protection of the non original photographs of Art. 72 to the photographic works of Art. $2 .{ }^{190}$ The main difference relates to the term of protection as the duration of the exclusive rights for non original photographs is limited to 50 years after publication or production. ${ }^{191}$

A photograph is protected pursuant to Art. 72 in those cases when a very low original content is present and therefore includes amateur photography, such as "point-and-shoot" pictures, where the space for free and creative choices is almost absent. ${ }^{192}$ However, a minimum level of originality is still necessary, although inevitably lower than that of Art. 2, and can be expressed, for example, through the determination of the shooting conditions. ${ }^{193}$ Accordingly, simple photographs are protected as long as they possess a "minimum of personal intellectual input" as opposed to the requirement of "personal intellectual creation" that Art. 2 demands for photographic works. ${ }^{194}$

In light of the aforementioned conditions, it seems plausible that a perfect digitisation of a text, document, or image, realised by processes such as digital scanning or photocopying will most likely fall outside the scope of protection of Art. 72 and constitute mere reproductions. This is certainly the case for the mechanic digitisation of books as same the Supreme Court established. ${ }^{195}$

A different conclusion, however, could be reached when the digitised element is not a text or an image, but a three-dimensional object. In the latter case, there will most likely be a human operator who, in a process that can be assimilated to photography, will most probably place the item in the best position in terms of light, angle, height and/or perspective in order to render in the picture as many details of the object as possible. In such a case, while the intent of the photographer is certainly that of reproducing the reality as closely as possible, therefore excluding any personal stamp, the protection of simple photographs may be available inasmuch as the result reflects the author's minimum intellectual input. This remains, nonetheless, a very contentious issue, and the

188 Dietz suggests that the two standards, the German "personal intellectual creation" and the EU "author's own intellectual creation", are equivalent; See Dietz A., in Geller \& Bently, 2[1][b].

189 See Art. 72(1) UhrG.

190 See Wiebe A., Schutz der Lichtbilder, in Spindler \& Schuster, 2011.

191 See Art. 72(3) UhrG.

192 See Wiebe A., Schutz der Lichtbilder, in Spindler \& Schuster, 2011.

193 Id.; See also Case I ZR 55/97 (German Federal Supreme Court, BGH), of 3. 11. 1999, in MMR 2000, 218.

194 See Case I ZR 55/97 (German Federal Supreme Court) of 3.11.1999 (Schutz von Lichtbildwerken), in MMR 2000,218 (the Court, relying on previous case law, employed the expression "ein Mindestmaß an persönlicher geistiger Leistung" as opposed to the formula found in Art. 2 "persönliche geistige Schöpfungen").

195

See in this sense Case I ZR 14/88 (German Federal Supreme Court, BGH), of 08.11.1989(erstellung und Vertrieb einer Bibelreproduktion), in NJW-RR 1990, 1061 (excluding protection as simple photographs in case of mere duplication lacking any minimum of personal intellectual input). 
fact that the result of the digitisation process is a perfect reproduction of the three-dimensional object should weigh against the possibility that the picture be protected by either Art. 2 or Art. 72 German Copyright Act.

\section{France}

\subsection{Originality}

In France copyright is regulated in the Code de la Propriété Intellectuelle (Intellectual Property Code, IPC ${ }^{196}$ ). The object of copyright protection is a work of the mind (oeuvre de l'esprit) whatever the kind, form of expression, merit or purpose. ${ }^{197}$ French law protects specific, individualized and perfectly identifiable creations, not mere ideas. ${ }^{198}$ Protection is granted on the basis of the "seul fait de sa création" 199 and does not require any fixation. ${ }^{200}$

Included in the non exhaustive list of Art. 112-2 IPC are books, artistic and scientific writings, cinematographic works and other works consisting of sequences of moving images, with or without sound, works of drawing, painting, architecture, sculpture, photographic works and works produced by techniques similar to photography.

French copyright law does not require that a specific work falls within one of the categories of literary, musical, dramatic and artistic works, nor does it require that one of the types of protected works is included in the non-exhaustive list of Art. L.112-1 be met. ${ }^{201}$

The concept of "originality" was systematically approached only relatively recently by the French doctrine. ${ }^{202}$ Although the specific formulations employed by scholars and the courts may vary, the generally accepted standard is that of the stamp of the author's personality or l'empreinte de la personnalité de l'auteur. ${ }^{203}$

In order to verify whether the author's personality is present in the work, French courts usually enquire whether he had the possibility to choose among a number of possible expressive forms, and by choosing one instead of another, he expressed his personality. ${ }^{204}$ In other words, in order to

196 Code de la propriété intellectuelle created by Loi $n^{\circ} 92-597$ of 1 July 1992, as amended.

197 See Art. L.112-1 IPC.

198 See Lucas \& Kamina; in Bently \& Geller, at 2[1][b][ii].

199 See Lucas \& Lucas, 2012, at 59.

200 See Art. L.111-1 IPC.

201 See Lucas \& Kamina; in Bently \& Geller, at 2[1][b][ii][C].

202 Lucas \& Lucas, 2012, at 118.

203 See e.g. Supreme Court (Cour de Cassation), 10 July 2013 n. 12-19170 [Sté Nereides]; 24 June 2014, n. 13-12067 [Sté Weston]; Court of Appeal of Paris, 11 sept. 2013, n. 11-22046, [Sté. Repetto]; Lucas \& Lucas, at 119; Judge \& Gervais, 2009, at $378-379$.

204 See Supreme Court (Cour de Cassation) 13 May 2014, n. 12-27691 [Sté Xooloo]; Lucas \& Lucas at 120; Gervais \& Judge 2009, at 380; Employing the same expression ("l'empreinte de personnalité de l'auteur") see Tribunal d'Arrondissement 
establish whether the threshold of the l'empreinte de la personnalité is achieved, courts verify whether in the process of creation of the work enough creative choices have been made. ${ }^{205}$ This formulation of the originality standard and of the related test seems in line with the latest ECJ case law. ${ }^{206}$

\subsection{Derivative works}

Art. L.112-3 IPC establishes that the authors of translations, adaptations, transformations or arrangements of works of the mind shall enjoy protection without prejudice to the rights of the author of the original work. ${ }^{207}$ A translation or adaptation will be protected by copyright if it is original, which will be evaluated on the basis of the presence of the translator's or adapter's personality in the resulting derivative work..$^{208}$

In a decision on musical works, the Court of Appeal of Paris stated that a musical arrangement is original if the arranger added, modified or deleted certain parts of the primary work and in this way he expressed his own personality in the derivative work. ${ }^{209}$ Regarding translations, courts ruled that they are protected by copyright if "the author can express his creativity in an original manner and achieve a result which is an intellectual creation". ${ }^{210}$

Article L.113-2 paragraph 2 Intellectual Property Code defines a "composite work" as "a new work in which a pre-existing work is incorporated without the collaboration of the primary author". A composite work therefore refers to simple incorporations (e.g. music synchronized in a film) and to adaptations (e.g. a remake or an adaptation of a book into a film). A composite work is the property of the author who has produced it, subject to the rights of the author of the pre-existing work. ${ }^{211}$

\subsection{Photographs and non original photographs}

Photographic works, which include works produced by techniques analogous to photography are protected when they reach the required level of originality. Examples of creative choices that can lead to the necessary level of originality in the creation of photographic works can be identified in the selection of shots, in the adjustment of camera angles and lighting, or in the staging or preparatory acts leading to the taking of the photograph. ${ }^{212}$

\footnotetext{
Diekirch (Luxemburg) decision 169/2003, 8 August 2003, LJUS n 99844360 , reported by the Luxembourg correspondent. 205 Judge \& Gervais, 2009, at 381.

206 See above part I.

207 See Art. L.112-3

208 See Lucas \& Kamina; in Bently \& Geller, at 2[3][a].

209 See Court of Appeal of Paris, of 17 Dec. 2010, 06/15843, in 69 Revue Lamy Droit de l'Immatériel, 2011 at 2266.

210 See Court of Appeal of Paris, 6 February 2002, 2001/17352.

211 See Article L.113-4 Intellectual Property Code.

212 See Lucas \& Kamina, in Bently \& Geller, at 2[2][b].
} 
French copyright law does not afford special neighbouring right protection to non original photographs. ${ }^{213}$

Interestingly, the Court of Appeal of Paris held that a photograph of a work of art may be original due to its own photographic features and therefore lead to an "oeuvre composite". ${ }^{214}$ In this case, the photographer, taking pictures of works of art during an exhibition, chose the moments of the click, the type of illumination and the angles of the photograph, thereby demonstrating creativity and the stamp of his personality. It must be noted, nonetheless, that in the referred case the work of art was a moving object, an aspect that was central in the holding of the court which focused on the fact that the photographer had to choose the right moment during the swinging of the object in order to represent properly the work of art. This choice of time, light and angle was held not to constitute a mere application of technical knowledge, notwithstanding the fact that in the case at issue the plaintiff argued to have given specific instruction to the photographer on how to realise the pictures. ${ }^{215}$ Similarly, in another decision the Cour de Cassation found that a photographer put his personal stamp on the photographic work by choosing the most opportune moments and ways to realize the picture. ${ }^{216}$

Nevertheless, in order to find that a photograph deserves copyright protection, it is mandatory for courts at trial to determine on a case by case basis whether the author stamped his creativity on the work. ${ }^{217}$ Consequently, it has been ruled that a number of photographs of the city of Paris which were automatically taken by a camera placed on an aircraft and where the "operator" could only determine the moment of the shot, but not the angle, light and other parameters did not show the personality of the author and consequently did not attract copyright protection. ${ }^{218}$ In this case, the Court stressed that even though the pictures were realised with great skill ("elles sont le fruit du travail d'un excellent technicien doté d'un équipement performant") they lack an original character and do not carry the stamp of the author's personality: The pictures would have looked the same if taken by another technician placed in the same situation. ${ }^{219}$ Recently, the Supreme Court held that a photograph was not protected as a work of authorship because "la photographie revendiquée ne révélait, dans les différents éléments qui la composent, aucune recherche esthétique et qu'elle constituait une simple prestation de services techniques ne traduisant qu'un savoir-faire". ${ }^{220}$ While the pursue of an aesthetic research seems not to be contemplated by the requirements set forth by the Term Directive and further interpreted by the ECJ, especially in Infopaq and Painer, it can certainly be inferred from such rulings, that the perception that French courts have of the requirement of originality, particularly in photographs, is probably higher than what available in other countries. ${ }^{221}$

213 For an account documenting a legislative initiative to introduce a form of protection for, inter alia, non original photographs, see Le Stanc, 1992.

214 See Court of Appeal of Paris 5 May 2000, in RIDA 2001, n. 188, at 352; See Markellou, 2013.

“[...] la nature de l'éclairage et de l'angle de prise de vue adoptés pour faire ressortir au mieux les couleurs et les volumes de la sculputre temoignent d'un choix personnel du photographe et portent l'empreinte de sa personalite"; See Court of Appeal of Paris 5 May 2000, in RIDA 2001, n. 188, at 352, at 356.

216 See French Supreme Court (Cour de Cassation) of 12 January 1994, n. 91-15718.

217 See Cour de Cassation of 14 November 2000, n. 98-18741.

218 See TGI Paris, 6 Oct. 2009, RIDA, 2010, no. 226, 506.

219 Id., at 508; In a similar direction see Cour de Cassation 1 March 1988, n. 86-12213, denying protection for shots of a technician.

220 See Cour de Cassation, 20 October 2011, n. 10-21251.

221 Confront this standard with the one employed by the Patent County Court in Temple Island Collections Ltd v. New English Teas Ltd, [2012] EWPCC 1, discussed below. 
Interestingly, it is reported that in 2010 a court of first instance excluded from protection a large number of photographs of works of art for auction catalogues, as they lacked originality because "the photographer was not asked to show any emotion, as it is the object for sale that must be put forward (for the auctions) and not the personality of the author of the photograph". ${ }^{222}$ The Court of Appeal of Paris reversed this ruling, giving a different evaluation of the choices operated by the photographer, in particular in relation to the positioning of the objects, the framing, the angles, the use of the shadows and light and the creation of a background. ${ }^{223}$

In conclusion, it seems possible to exclude that acts of automatic digitisation of books and images fall within the scope of protection of photographic works. This includes situations where a human intervention is present, as long as the human contribution is that of a technician, that is to say where there is no personality of the author because any other technician would have produced the same result. The case of object of art is, as usual, borderline. Not every photograph of a three-dimensional work of art will be protected, but only those photographic works that add the personality of the author to the already existing work of art.

\section{Spain}

\subsection{Originality}

The Spanish Copyright Act (TRLPI ${ }^{224}$ ) affords protection in general to "literary, artistic and scientific works" 225 which constitute "original creations" 226 expressed in any manner or medium and contains the usual non-exhaustive list of protected subject matter ("comprendiéndose entre ellas"); fixation is not required.

In courts' interpretation the concept of originality has evolved over time and recent case law has found originality in very simple creations, such as notebooks for elementary school use ${ }^{227}$ or a booklet of instructions on how to install and use a shower screen. ${ }^{228}$ Nevertheless, a "formal expression" is essential and consequently not only ideas, but also methods, formulas, and "themes" have been denied protection. ${ }^{229}$

\footnotetext{
See High Court of First Instance of Paris, 30 November 2010, No. 09/04437 cited in Spitz 2015, at 15.

223 See Court of Appeal of Paris, decision of 26 June 2013, No. 10/24329, cited in Spitz 2015, at 15.

224 Texto Refundido de la Ley de Propiedad Intelectual (TRLPI), approved by Royal Legislative Decree 1/1996 of April 12, as amended.

225 Art. 1 TRLPI

226 See Art. 10(1) TRLPI.

227 See Spanish Supreme Court (Tribunal Supremo) of 7 June 1995, n. STS 3284/1995 (ECLI:ES:TS:1995:3284).

228 See Spanish Supreme Court (Tribunal Supremo) of 30 January 1996, n. STS 7779/1996 (ECLI:ES:TS:1996:7779).

229 See Bercovitz \& Bercovitz \& Corral, in Geller \& Bently, 2[1][b] and case law cited in fn. 5, in particular Court of Appeal of Barcelona, 22 February 2005, n. 118095 (denying protection to a method of practising sport).
} 
All the same, case law is not uniform on the concept of originality. For example, floor plans were denied protection because "they do not bring anything new to the cultural acquis and their only goal is to be used as models or standards so that the technician or the user can execute them". ${ }^{230}$ On the other hand, however, the Supreme Court granted protection to works with a very low creative input, such as the content of the job ads section of a newspaper. ${ }^{231}$

\subsection{Derivative works}

Similarly to France, Spanish law explicitly recognises protection to "composite works" which are defined as new works that "incorporate a pre-existing work without the collaboration of its author." 232

Moreover, Art.11 TRLPI grants protection to derivative works such as translations, adaptations, revisions, musical arrangements and any transformation of a literary, artistic, or scientific work. As usual, protection is afforded without prejudice to the rights in the original work. ${ }^{233}$

Derivative works and composite works must be "original creations" in order to attract protection in their own right. In literature the elements of "proportionality" as well as "autonomous and substantial novelty" have been identified in order to explain the generation of a new work which has been integrated into or derived from the pre-existing one. ${ }^{234}$ Authors of derivative works will be granted protection only in relation to the new authorial additions, although in practice it might be hard to determine where the primary works ends and the secondary starts. ${ }^{235}$

\subsection{Photographic works and non original photographs}

Spanish TRLPI not only grants protection to photographic works as original creations, ${ }^{236}$ but also to "mere photographs", although the distinction is not clearly specified in the Copyright Act, which, slightly tautologically, only establishes that mere photographs are those not protected by Art. $10 .{ }^{237}$

According to the Supreme Court, the distinction between a photographic work and a mere photograph lies in the existence of some "creative relevance" that could meet the standard of "original creation" bearing the personality of the author. ${ }^{238}$ Analogously, it has been held that the

\footnotetext{
230 See AP Barcelona (sec.15) September 29, 2006 [Kitchen floor plans], translation provided by Spanish correspondent.

231 See Spanish Supreme Court (Tribunal Supremo) of 13 May 2002, n. STS 3347/2002 (ECLI:ES:TS:2002:3347).

232 See Art. 9(1) TRLPI

233 See Bercovitz \& Bercovitz \& Corral, in Geller \& Bently, 2[3].

234 See Xalabarder, in Hilty \& Nérisson (eds.), 2012, at 930.

235 Id.

236 See Art.10(1)(h) TRLPI.

237 See Art.128 TRLPI.

238 See Spanish Supreme Court (Tribunal Supremo), 5 April 2011, n. 214/2011, which denied protection to photographs of food products taken for a food catalogue arguing that they lack the minimal amount of creativity required to meet the standard of
} 
circumstance that the author incorporates into the work "the product of his intelligence", i.e. an act of very personal character, leads to the creation of a photographic work. ${ }^{239}$

On the other hand, courts denied the qualification as photographic works to some photos published as part of an encyclopedia because the fact that the photographs were taken with technical precision is not relevant to qualify them as photographic works "por muy complejo que haya sido el procedimiento de obtención del ejemplar fotografiado" but were accorded protection as "mere photographs". ${ }^{240}$ Interesting to note the fact that in this case, in order to obtain the photograph, aspects such as the selection of the lenses, lighting, use of the right combination of filters, adjustment of the tripod and selection of the diaphragm were considered mere technical activities not personal enough as to consider the photograph the "daughter of the intelligence, ingenuity and inventiveness of a person". ${ }^{241}$ Nevertheless, choosing the light, angle and frame of the photo can qualify photographs as works as long as "they are the result of their author's intelligence and not a mere reproduction of an image". ${ }^{242}$

Mere photographs enjoy the exclusive right of reproduction, distribution and communication to the public on the same terms as they are accorded to the authors of photographic works, with one major exception: protection only lasts 25 years from production. ${ }^{243}$ In principle, no moral rights are granted to the maker of a mere photograph. ${ }^{244}$ Interestingly, the Act does not mention the right of adaptation within the rights granted by Art. 128, which lead courts to deny the existence of this prerogative to makers of mere photographs. ${ }^{245}$

Acts of digitisation seem excluded from the protection afforded by photographic works in all those cases where it is not possible to identify the author's personality. This is certainly the case in processes of digitisation of texts and images which are largely automated or semi-automated. In cases of objects, once again, it must be established on a case by case basis whether the personality of the author is present in the photograph, which seems to be an unlikely outcome when the result sought is to document, not reinterpret, the reality. The protection granted by Art. 128 seems to be available in the latter case, i.e. photographs of three-dimensional objects which usually require some basic, technical, and usually not creative decision. The automated or semi-automated digitisations of books and images, nevertheless, seems to fall outside the scope of mere photographs in that it is only an act of (digital) reproduction.

"original creation": the technique of "painting with light" which is very common in professional food catalogue professional photographers does not meet the standards of creativity and originality, and therefore the available protection is that of "mere photographs"; See also Tribunal Supremo, 24 June 2004, n. 542/2004.

239 See Spanish Supreme Court (Tribunal Supremo), 29 March 1996, n. STS 7969/1996 (ECLI:ES:TS:1996:7969).

240 See Court of Appeal of Barcelona (Audienica Provincial) of 29 July 2005, n. SAP B 7715/2005 (ECLI:ES:APB:2005:7715) [Enciclopedia Catalana]. In the same sense, other rulings by the same court: Court of Appeal of Barcelona 20 December 2004, n. SAP B 15228/2004 (ECLI:ES:APB:2004:15228) [El Mundo de los Insectos] denying copyright protection to some photos of butterflies regardless of the technical effort and precision (lighting, angle, etc) involved in taking them. Similarly, denying moral rights protection to mere photographs done by a free-lance photographer for a newspaper, see Spanish Supreme Court 31 December 2002, n. STS 8943/2002 (ECLI:ES:TS:2002:8943) [Diario ABC].

241 See Spanish Supreme Court (Tribunal Supremo), 7 June 1995, n. STS 3284/1995 (ECLI:ES:TS:1995:3284).

242 See Court of Appeal of Barcelona (Audiencia Provincial), September 10, 2003, n. SAP B 4681/2003 (ECLI:ES:APB:2003:4681) [Cabo de Creus]. In this case, the photos had been published by a newspaper without mentioning the name of the author (a well-known professional who had received several distinctions and awards for his professional work and had also published a manual on photography.

243 See Art. 128 TRLPI.

244 See Spanish Supreme Court 31 December 2002, n. STS 8943/2002 (ECLI:ES:TS:2002:8943) [Diario ABC] denying any infringement for the publication of some mere photographs without mentioning the author's name.

245 See Bercovitz A., Bercovitz G., Corral M., in Geller\&Bently, 9[1][a][v]. 
Some supporting guidance on the latter aspect may perhaps be found in a case dealing with the different issue of the reproduction of a (literary) work in the public domain, which, under Spanish law, is potentially protected by a related right on typographical arrangements of public domain works. ${ }^{246}$ In this case the Court only considered whether or not the new edition had enough "singularities" to qualify for protection and concluded against it. The court ruled that the "mere reproduction of a work in the public domain, despite being technically perfect and sophisticated, did not have any singularity that could make the publication distinguishable from others". ${ }^{247}$

\section{Italy}

\subsection{Originality}

Italian copyright law protects works of ingenuity of creative character (opere dell'ingegno di carattere creativo) belonging to the fields of literature, music, arts, architecture and cinematography, regardless of the manner or form of expression. ${ }^{248}$ Art. 2 offers a non-exhaustive list of subject matter to illustrate what types of works can find recognition under the general categories listed under Art. 1.249

The open-ended nature of Art. 2 is confirmed by the plain meaning of the provision ("in particolare") and serves the purpose of illustrating which kind of subject matter can fall within the categories of Art. 1. This aspect has never raised particular debate among scholars or courts and in the past, new forms of expression not contemplated by previous formulations of Art. 2, such as photographs or computer programs, were considered protected by extensive judicial interpretation long before statutory intervention. ${ }^{250}$

Regarding Art. 1, however, views are not uniform. It has been argued that it exhaustively lists the protected categories within which the subject matter illustratively enunciated in Art. 2 has to find proper place. ${ }^{251}$ In particular, one author submitted that the concept of work of authorship and the categories included in Art. 1 are flexible enough to be extensively interpreted to include new technological developments and forms of expression. Nevertheless, they constitute a numerus clausus which cannot offer protection to any intellectual creation whatsoever. ${ }^{252}$ Accordingly, a hypothetical new form of expression made possible by technological evolution should be tested

\footnotetext{
246 See Art.129.2 TRLPI. This aspect has been suggested by the Spanish correspondent.

247 See Commercial Court of Madrid (Juzgado de lo Mercantil) of 14 June 2005, n. AC/20051078 [Libro de Horas de Carlos V].

248 See Art. 1 Italian Copyright Act of 1941 ("Legge 22 aprile 1941, n. 633 sulla Protezione del diritto d'autore e di altri diritti connessi al suo esercizio") as amended. A similar definition is present in Art. 2575 of the Italian Civil Code.

249 See Autieri et al., 2012, at 548.

250 See Autieri et al, 2012 at 548.

251 See Fabiani M., Il diritto d'autore, in Rescigno, 1983, 132; Marchetti \& Ubertazzi, 2012, at 1326; Autieri et al., 2012, at 548

252 See Autieri et al., 2012 at 548.
} 
against the categories listed in Art. 1: failure to fall within one of these typified categories would lead to the denial of copyright protection. ${ }^{253}$

It is clear from Art. 1 definition that only an expressive form is protected and not the underlying idea; however, as seen for other continental copyright systems no fixation requirement is present. ${ }^{254}$ Regarding the type of originality required, the literal element present in the Act explicitly refers to creativity. Creativity is usually identified as "simple" in the sense that it is present when the author operates discretionary choices in relation to the forms to express an idea within a sufficient number of alternatives. ${ }^{255}$ This concept of creativity seems perfectly in line with the recently EU harmonised standard of the "author's own intellectual creation" 256 and it has led Italian scholars and courts to the attainment of principles similar to those identified by the ECJ. ${ }^{257}$

\subsection{Derivative works}

Art. 4 of the Italian Copyright Act affords protection to creative elaborations of works, such as translations in another language, transformations from a literary or artistic form into another one, modifications or additions that constitute a substantial remake of the original work, adaptations, "reductions" (intended as shorter versions of protected works), compendia, and variations which do not constitute original works. Protection is granted without prejudice to the rights existing on the primary work.

Consequently, derivative works constitute a distinct work independent but derived from the primary, which is protected as long as it shows the required degree of originality in its own right. ${ }^{258}$ Naturally, works that are only inspired by other works but not derived from them, constitute independent, primary creations and are protected accordingly.

The Italian Supreme Court, in a case on drawings inserted in a tourist guide of the city of Venice, established that creative elaborations are characterized by the presence of a recognizable creative contribution in the derivative work and found that the disputed images were creative elaborations of previous pictures of the city. ${ }^{259}$ The creative contribution consisted in choosing a two-dimensional rather than a three-dimensional perspective and a "black and white" style rather than the original colour. Similarly, it was found that adding a soundtrack to a silent movie or making a rock-and-roll song from a piece of classical music constitute creative elaborations. ${ }^{260}$

\subsection{Non original photographs}

\footnotetext{
253 No case law on this specific matter has been found.

254 See Marchetti \& Ubertazzi, 2012, at 1328.

255 See Marchetti \& Ubertazzi, 2012, at 1330.

256 See above Sec. 2.2

257 See Marchetti \& Ubertazzi, 2012, at 1330.

258 See Piola Caselli, 1943, at 234; Greco \& Vercellone, 1974 at, 83; Marchetti \& Ubertazzi, 2012, at 1330.

259 See Italian Supreme Court (Corte di Cassazione) 27 October 2005, n. 20925.

260 See Court of Appeal of Milan, 19 December 2000, and Tribunal of Milan (court of first instance), 31 May 1999.
} 
Until 1979 the current Italian Copyright Act protected photographs only by way of a related right whose term of protection was set to 20 years from creation (or 40 years in cases of photographs of figurative art and of architectural works). ${ }^{261}$ Nevertheless, even before the explicit inclusion of photographs as a protected subject matter scholars argued that when general requisites of copyright protection were present, photographs could be considered as artistic works. ${ }^{262}$

Following the 1979 reform, Art. 2 n. 7 afforded protection to photographic works and works realised with processes that can be assimilated into photography, except in the case of "simple photographs" which are specifically regulated in Art. 87.

In accordance to the current legal situation, original photographic works attracting full copyright are those that incorporate the personality of the author which is manifested through elements such as the choice and the combination of visual effects, or the composition of the subject/object of the picture. ${ }^{263}$ Creativity, it has been argued, can also be present in the "sensitivity of the photographer who is able to catch the moment in which the reality manifest itself" in unique images, which, once fixed on film, can be enjoyed by the public. ${ }^{264}$

In literature, especially in the past, it was argued that in order to qualify for copyright protection photographs needed to possess an evident creative contribution of the author. Similarly, courts interpreted the creative requirement in the sense of a particularly high level of originality. ${ }^{265}$ More recently, however, both literature and case law seem to have adopted a different approach whereby the originality threshold of photographs is aligned to the same level as that of other subject matter. ${ }^{266}$ This approach seems in line with EU law and recent ECJ case law. ${ }^{267}$

The Italian Copyright Act affords specific protection to non original photographs or "simple photographs". Accordingly, Article 87 establishes that the images of persons or of aspects, elements or events of natural or social life, obtained by photographic or analogous processes, including reproductions of works of figurative art and photograms of cinematographic film, shall be protected by a right related to copyright. This right lasts 20 years from the date of production and grants the maker of the photograph the right of reproduction and distribution and, most likely, the right of adaptation; moral rights, however, are not explicitly recognised. ${ }^{268}$

The form of protection under scrutiny focuses on the technical competence of the operator who realises the photographs and on his ability to capture the moment represented in the picture. ${ }^{269}$ Consequently, the requirement for this peculiar form of protection is the special "technical know-

261 See Law (Decree of the President of the Republic, d.p.r.) 8 January 1979, n.19 amending the Italian Copyright Act. At the basis of the reform was the consideration that the term of protection of 20 years (instead of the 25 year term mandated by Berne) and the absence of moral rights recognition was not in full compliance with Italy's international obligations; See generally Autieri et al, at 568. Under the old Copyright Act of 1865 photographs were not protected until a 1925 legislative reform that recognised them as a copyright subject matter, but limited their protection to 20 years; See Marchetti \& Ubertazzi, 2012, at 1338. See Marchetti \& Ubertazzi, 2012, at 1338. Id.

65 See Greco \& Vercellone, 1974, at 385; Fabiani, 1969, Court of first instance of Florence (Trib. Firenze), 16 February 1994, in Dir. Aut., n. 3, 1994, 480; Mezzetti, 2012, at 12.

266 See Autieri et al., at 568; Marchetti \& Ubertazzi, 2012, at 1338.

267 See above Part I.

268 See Marchetti \& Ubertazzi, 2012, at 1662.

269 See Ubertazzi, 1998. In case law, Court of first instance of Milan (Tribunale Milano) 9 November 2000, in AIDA, 2002, 831; Court of first instance of Rome (Trib. Roma), 24 February 1998, in Dir. Inf., 1998, 793. 
how" of the photographer, which must be kept distinct from the original personal interpretation of the author. ${ }^{270}$

Nonetheless, if photographs are intended to merely reproduce existing objects or documents they will not benefit from any form of protection. This can be inferred from the second part of Art. 87 which establishes that photographs of writings, documents, business papers, material objects, technical designs and similar products are not protected. Therefore, provided that photographs only perform a pure documentation function protection is excluded. According to the Italian Supreme Court, documentation purposes are excluded from the scope of protection of simple photographs and consequently so long as photographs pursue objectives other than documentation they qualify for protection even if they reproduce material objects. ${ }^{271}$ The ratio of the norm is to deny protection in cases of mere reproductive photographs of material objects which are intended to merely "document" the object, without an appreciable effort of the technical and professional abilities of the photographer and of his inventiveness" 272

Art. 90 establishes specific conditions in order to enjoy the protection afforded by the related right. Accordingly, simple photographs must indicate the name of the photographer (or of the employer/commissioner), the year of production and the name of the photographed work of art. ${ }^{273}$ These conditions are not constitutive of the right, but required in order to make the remedy readily available to the plaintiff: their absence will permit unauthorized reproductions, including in absence of the fair compensation provided for in the remainder of the Act, unless the photographer proves the bad faith of the reproducer.

Accordingly, acts of automated digitisations are excluded from the protection granted to photographic works and to other photographs. Only photographs that show the personal input of the author can be protected by copyright. When the input of the photographer consists in his technical know-how but does not achieve the more demanding threshold of a personal stamp, non original photograph protection may be available, but only at the conditions outlined above.

270 See Court of first instance of Milan (Tribunale di Milano), specialized section in intellectual property, of 11 October 2006, in IDA 08,83 (holding that the photograph of a famous artist during a performance does not contain the personal input of the author).

See Italian Supreme Court (Corte di Cassazione) 21 giugno 2000, n 8425, in AIDA 2000.

272 Id. According to a different approach the second paragraph of art. 87 excludes from protection all mechanical reproductions of material objects; See Sarti, 2000. Yet another approach suggested that the mechanical process would generally exclude any exclusive right; See, Court of first instance of Milan (Trib. Milano), 7 September 2000, in AIDA 2001, 565.

In the case of a photograph of a work of art, although the Act remains silent at this regard. 


\section{Poland}

\subsection{Originality}

The Polish Copyright Act affords protection to any manifestation of creative activity of individual nature, expressed in any form irrespective of its value, purpose or form of expression (art. 1.1). ${ }^{274}$ Art. 1.2 lists among other protected works literary, artistic and photographic works.

A creative activity of individual nature requires that a work is novel to the author and that it is not copied. ${ }^{275}$ Evidence of creativity could be found in the fact that a work was not the result of routine mechanical work, nor fully determined by its assumed goal or function, but rather the outcome of its author's personal or individual decisions and choices. ${ }^{276}$ In order to ascertain whether the "creative activity" is present, the Supreme Court indicated to inquiry whether a work is "characteristic of a given artist and bears characteristic features which enable it to be distinguished" from other works. $^{277}$

Additionally, in a recent decision the Supreme Court introduced the test of "statistical uniqueness" in order to determine whether the work possesses individual character. According to the Court, "examining whether an identical or a very similar work has been created earlier and whether creating an identical work by another person in the future is statistically probable" is a decisive factor. In the case of a negative finding, "the existence of the individual character of the work" is likely. ${ }^{278}$

Nevertheless, the originality standard set by courts should not be placed at particularly high level. In another recent decision, the Supreme Court granted copyright protection to a "calories calculator" constituted by two paper circles which could be rolled to present some general facts about nutrition. ${ }^{279}$ On the other hand, however, the same court declined protection to reproductions of official symbols used on Police uniforms such as Polish coat of arms and ranks distinctions, which were claimed to constitute creative derivatives of the unprotected official materials. ${ }^{280}$

\subsection{Derivative works}

Article 2 of the Polish Copyright Act establishes that a work derived from another work, in particular its translation, modification or adaptation, shall be the object of copyright without prejudice to the rights in the original work. The originality required in cases of translations and

\footnotetext{
274 See Law n. 83 of February 4, 1994 on Copyright and Neighbouring Rights, as amended (the English version here referred to is the one available on the WIPO website and updated to the last amendment of October 21, 2010).

278 See Polish Supreme Court, 27 February 2009, V CSK 337/08, OSP 2010/3/33, reported in Barta \& Markiewicz, in Geller \& Bently, 2013, at 2[1][b].

279 See Polish Supreme Court, 25 January 2006, I CK 281/05 (reported and translated by the Polish national reporter).

280 See Polish Supreme Court, 13 January 2006, III CSK 40/05 (reported and translated by the Polish national reporter).
} 
adaptations is of the same kind as for primary works and has to be ascertained throughout the same tests. $^{281}$

Sec. 4 of Art. 2 clarifies that the work produced under the mere inspiration of another author's work shall not be considered as a derivative work. In order to be considered a derivative work, the adaptation needs to incorporate enough creative elements from the prior work, so that the new work communicates the contents of the prior one..$^{282}$

The primary work right-holder's consent is of course necessary for any creation and exploitation of a secondary, derived work (Art. 2.2). The Act permits the owner to withdraw his or her consent if the derivative work has not been exploited within five years from the date in which the consent was given. ${ }^{283}$ Art. 2.5 establishes that copies of the derivative work must identify the original author and the title of the primary work.

\subsection{Photographic works and Non original photographs}

As seen above, Polish legislation recognises protection to photographic works which are explicitly listed in Art. 1.2 n.3; no special protection is available for non original photographs.

In a 1998 decision, ${ }^{284}$ the Polish Supreme Court evaluated the originality of photographies comprised in a museum collections and realised by an employee whose assigned task was to gather "photographic documentation of museum's objects". The court ruled that the photographs were not original arguing that the employee was instructed to prepare representations of the collection not in a creative, but in a "reproductive" way, that is to say "only the art of the painter was meant to be visible, not the art of the photographer". ${ }^{285}$

The decision, while representing an important precedent in the field of photographic works objectively representing reality, attracted some criticism. It is reported that the court based its reasoning on the content of the agreement reached by the two parties, which may well be used to determine the fate of negotiable copyright elements (e.g. transfer or reservation of rights, joint ownership, specific monetary compensations), but cannot be used to determine whether a work of authorship has been created. ${ }^{286}$ The latter condition should transcend the intention of the party or parties involved in the creative process and only focus on the original creative result. ${ }^{287}$

In another case, a photograph of a painting was considered not copyrightable since it merely reproduced "a defined set of colours without any alterations in their internal characteristics". In the

\footnotetext{
281 See Barta \& Markiewicz, in Geller \& Bently, 2013, at 2[3].

282 Id.

283 See Art. 2.3 Polish Copyright Act.

284 Polish Supreme Court, 26 June 1998, I PKN 196/98, (reported and translated by the Polish national reporter).

285 Id

286 While this criticism is certainly correct, it must also be noted that often - and in particular in difficult cases - Courts look at any possible factual basis in order to determine whether the results of the efforts of the photographer possess any additional creativity. Therefore, it is plausible that the intention of the author is evaluated as an historical antecedent that contributed to the 287 achievement of said result; See Barta \& Markiewicz, in Geller \& Bently, 2013, at 2[3]. Id.
} 
opinion of the court only a photograph susceptible of being "treated as an interpretation" of the painting could constitute a "creative activity" and therefore be protected by copyright. ${ }^{288}$

In the light of the above, it seems that acts of digitisation of texts and images are certainly outside the scope of photographic works, since "only the art of the original author and not that of the photographer" should be visible. The same conclusion seems to hold true for the digitisation of objects, in all those cases where the digitisation is a mere digital reproduction of the object. Nevertheless, it must be kept in mind that the level of originality should not be mistakenly placed at a too high standard: the free and creative choices of a creative photographer, which need to be assessed on a case by case basis, could, especially in cases of "artistic" photography of works of art, be considered authorial.

\section{UK}

\subsection{Originality}

In the United Kingdom copyright law is regulated pursuant to the Copyright, Design and Patents Act 1988 (CDPA 1988). Copyright protection is recognised to literary, dramatic, musical, and artistic works, films, sound recordings, broadcasts, and published editions (or typographical works). The UK Act lists exhaustively the categories of works that can qualify for copyright protection and consequently a work, in order to enjoy copyright protection, has to fall within one of the aforementioned eight categories. ${ }^{289}$

In order to attract protection under the CDPA, works must be original, at least for literary, dramatic, musical and artistic works. In contrast, sound recordings, films, broadcasts and typographical arrangements do not need to be original and it suffices that they are not copied from previous works. ${ }^{290}$ Fixation is an explicit requirement for literary, dramatic and artistic works, which need to be recorded in a material form. ${ }^{291}$

The concept of originality traditionally applied in the UK by courts is that of "skill, judgement and/or labour" ${ }^{292}$ or variations thereof, where words such as "capital", "effort", "industry", "time", "knowledge" and similar have been employed over time by different courts. ${ }^{293}$ It has been noted, however, that "much of the case law seems inconsistent and, according to one commentator the dividing line between original ... works, and unoriginal . . . works, remains an uncertain and shifting one". ${ }^{294}$

\footnotetext{
288 See Court of Appeal, Warsaw, July 5, 1995, I Acr 453/95, reported in Barta \& Markiewicz, in Geller \& Bently, 2013, at 2[3].

289 See Bently \& Sherman, 2014, at 58 and seq.

290 See Bently \& Sherman, 2014, at 92.

291 Id., at 91.

292 See Ladbroke v William Hill, [1964] 1 All ER 465.

293 See Bently \& Sherman, 2014, at 97.

294 Id, at 96 [citations omitted].
} 
Looking at the case law, it can certainly be said that some basic requirements are necessary in order for the British originality concept to arise. Accordingly, skill, judgement and labour must be substantial in amount and of the right kind. Regarding the former, face painting, titles and slogans have been found not original as the amount of labour in these cases was found to be insubstantial. ${ }^{295}$ Regarding the latter aspect, it has been found that a considerable amount of labour could not lead to an original result: "copying per se, however much skill or labour may be devoted to the process, cannot make a work original". ${ }^{296}$

Whether and to what extent the traditional standard of skill, judgement and labour survives, or more correctly, is compliant with the EU mandated standard of "author's own intellectual creation" will probably be discussed by courts and commentators in the years to come. Thus far, it can be said that UK courts have given recognition the new ECJ standard, but interpreted it as in line with the traditional UK one. ${ }^{297}$

Nevertheless, it must be noted that the same ECJ clarified that mere skill and judgement cannot lead to the "author's own intellectual creation", which is reached only through free and creative choices. ${ }^{298}$ It has been recently submitted that the two standards are simply different (although in large parts overlapping) and the UK traditional standard is not always "just lower" than the EU one. In particular, cases where very little labour was spent (e.g. 11 words), which nonetheless can constitute the author's own intellectual creation, might not necessarily pass the "skill, judgement and labour" standard. ${ }^{299}$

\subsection{Derivative works}

Sec. 21(3) CDPA establishes that translations, versions of dramatic works, and arrangements of computer programs, databases and musical works are acts reserved to the right-holder. Sec. 21(4) clarifies that in relation to a computer program a translation includes a version of the program in which it is converted into a different computer language or code. Accordingly, courts have protected compilations, translations, and adaptations of existing materials, as well as arrangements of music and engravings. ${ }^{300}$

However, in order to be protected the derivative work must have "some quality or character which the raw material did not possess, and which differentiates the product from the raw material". 301 Considerable labour and expertise are not sufficient to render an adaptation original and to qualify it as a protected derivative work. ${ }^{302}$ "There must in addition be some element of material alteration or embellishment which suffices to make the totality of the work an original work". ${ }^{303}$

\footnotetext{
295 See e.g. Merchandising Corporation v. Harpbond, [1983] FSR 32. 


\subsection{Photographic works and non original photographs}

The CDPA defines photographic works as recordings of light or other radiation on any medium on which an image is produced or from which an image may by any means be produced, and which is not part of a film. ${ }^{304}$ The CDPA does not offer explicit protection to non original photographs.

As seen in the first part of this study, Art. 6 of the Term Directive allows Member States to provide protection for "other photographs", meaning photographs that are not the author's intellectual creation. However, nothing is said about the type of protection that MS are allowed to provide for these non original photographs. ${ }^{305}$ The logical conclusion would be that interested MS should devise a special form of protection, or in any case a form of protection different from the one granted to original photographs (i.e. copyright). However, the Directive does not clearly state this, and it has been argued that non original photographs can be protected by standard copyright. ${ }^{306}$

As it has been noted, the better view is that the "protection of other photographs must be by means of a related right rather than copyright", which means that non original photographs are not protected under UK law. ${ }^{307}$ However, this point is not completely settled. Accordingly, it cannot entirely be discarded the eventuality that UK law protects both "EU original" photographs in virtue of the first part of Art. 6 Term Directive and "UK original" (i.e. skill, judgement and labour) photographs in virtue of the last part of Art. 6 by the same tool: copyright. ${ }^{308}$ Whereas acceptable on a purely theoretical level, this hypothesis it is not currently supported by any case law, nor by the dominant literature. ${ }^{309}$ For example, in Temple Island Collections Ltd v. New English Teas Ltd it was held that an image of a London double-decker bus was original in the European sense. ${ }^{310}$ The Court, in its reasons, acknowledged the harmonising effects of both Infopaq and Painer ${ }^{311}$ and borrowed the view of the Austrian Supreme Court in a decision in which it recognised (EU) originality in most amateur photographs. ${ }^{312}$

In dealing with digitisation of works of art under UK law, a reference to the "Graves' case" cannot be omitted. The case refers to the concept of originality in photographs of works of art under the old Copyright Act of 1862. Against a claim that such photographs cannot be considered original as they represent a copy of an already existing work, the Court replied that all photographs are copies of some object, yet they can be original. ${ }^{313}$ Subsequently, the Graves' Case, or more correctly its proper interpretation, was at the centre of the 1998 case Bridgeman I where a US court had to

\footnotetext{
304 See Sec. 4(2) CDPA.

305 See Article 6 and Recital 16 Term Directive which indicate that no criteria other than that of "the author's own intellectual creation reflecting his personality" can be applied to determining protection of photographic works, and aspects such as merit or purpose are explicitly excluded. On the other hand, the protection of other photographs is left to national law.$$
\begin{aligned}
& \text { case (C-5/08 [2010] FSR 20) was such that copyright may subsist in a photograph if it is the author's own "intellectual creation". } \\
& \text { After trial it was also common ground that the recent judgement of the CJEU in the Painer case (C-145/10, 1st December 2011) } \\
& \text { was to the same effect and did not necessitate further submissions from the parties", See Temple Island Collections Ltd v. New } \\
& \text { English Teas Ltd., [2012] EWPCC 1, at } 18 \text {. }
\end{aligned}
$$

312 See Case Austrian Supreme Court (OGH), decision of 16 December 2003, n. 4 Ob 221/03h [Weinatlas].

313 For a detailed account of the case see Deazley, 2010, 3, 293 - 331, citing the Graves' Case (1868-69) L.R. 4 Q.B. 715 at 723.
} 
decided whether, under UK law, a photograph of a work of art was protected. ${ }^{314}$ The US court denied protection to the photograph, a decision that attracted much criticism and a lively scholarly debate supporting one or the other position. ${ }^{315}$

Similarly, in Reject Shop, ${ }^{316}$ a case discussing enlarged photocopies' status, Leggatt L.J. observed that:

"the photocopying ... did not result in a depiction substantially different from the drawings themselves. He devoted to the copying ... no such skill and labour as conferred originality of an artistic character. The process was wholly mechanical and there is nothing to suggest that enlargement was for any purpose of that kind. There was, in short, no evidence before the magistrate of the exercise in the production of what he called the "distorted photocopies" of any relevant skill and labour whatever. It follows that the final images were not original works and so no copyright could subsist in them." 317

Likewise, in Antiquesportfolio.com, ${ }^{318}$ Neuberger J., holding in favour of the copyrightability of photographs of three-dimensional objects when enough skill is involved, ${ }^{319}$ admits that photographs of two-dimensional items represent a hard case:

"The only possible difference ... might be said to arise in the case of a purely representational photograph of a two-dimensional object such as a photograph or a painting",320

Nevertheless, Neuberger J. continues, it may well be the case that, if the photographer could show some degree of skill and care in taking the photograph, he could claim originality in a photograph of a two-dimensional item. ${ }^{321}$ The Court stresses that, whereas the case of two-dimensional objects is not a point that needs to be decided, English authority on the issue (i.e. photographs of both $2 \mathrm{D}$ and $3 \mathrm{D}$ works) is not much of assistance.

The better view is in all probability that a picture of a work of art, including a painting, cannot be excluded a priori from copyright protection just because the object photographed is not created or staged by the photographer. The deciding factor should be whether "taking the photograph leaves ample room for individual arrangements" such as motives, visual angles and lighting, ${ }^{322}$ that is to

314 See The Bridgeman Art Library Ltd. v. Corel Corporation, 36 F. Supp. $2 d 191$ (SDNY) 1999 [There are two judgements: On November 131998 Kaplan J. granted the defendant's motion for a summary dismissal on the basis of UK law. The plaintiff successfully moved for reconsideration and re-argument. On 26 February 1999 Kaplan J. granted again summary dismissal of the case on the basis of US law].

315 See Deazley, 2010, at 309. The interpretation given by the US Court to UK law is considered "probably wrong" by Cornish et al., 2013, at 444; See Garnett, 2000; Deazley, 2001; Stokes, 2001; Perry, 2003, at 696.

316 The Reject Shop Plc v Rober Manners [1995] F. S.R. 870, 876

317 Id. Se also Michalos 2004, at 3-019-3-020.

318 Antiquesportfolio.com Plc v Rodney Fitch \& Co Ltd [2001] E.C.D.R. 5.

319 Such as for instance "in the positioning of the object (unless it is a sphere), the angle at which it is taken, the lighting and the focus", in "the instant photographs appear to have been taken with a view to exhibiting particular qualities, including the colour (in the case of some items), their features (e.g. the glaze in pottery) and, in the case of almost all the items, the details" or in the choice "of the particular item in order to find a typical example of a certain type of artefact, or a particularly fine example of a certain type of artefact"; id., at $33-36$.

320 Id., at 31.

321 Id., at 33.

322 See Temple Island Collections Ltd v. New English Teas Ltd., [2012] EWPCC 1, at 20. 
say, to free and creative choices that can "embellish" the result. ${ }^{323}$ Of course, the fact that the object of the photograph is fixed and pre-existing, such as in the case of an object of art or a painting, instead of being created by the photographer, reduces considerably the space for such arrangements, but does not by itself exclude completely such a possibility. ${ }^{324}$ In these types of cases the court should verify whether the photographer was able to put the stamp of his personality on the photograph in the act of taking the picture and eventually in its post-production, or, on the contrary, whether it represents only a mere reproduction or a slavish copy. ${ }^{325}$

Accordingly, is to be excluded that mere acts of digitisation of text and images, which usually are based on automated or semi-automated processes, can give rise to new rights. This seems correct under the EU originality standard and most likely also under the "old" skill, judgement and labour standard, although in the latter case the tests to be applied may differ. For the case of objects of art, the considerations developed in the previous paragraph apply.

\section{The Netherlands}

\subsection{Originality}

The Dutch Copyright Act (Auteurswet ${ }^{326}$ ) protects original works in the literary, scientific and artistic fields (Art. 1) whatever the mode or form of expression and provides the usual nonexhaustive list of protected works in Art. 10.

The criterion of originality is not specified in the Act but has been recognised as a requirement for protection by the courts in several cases ${ }^{327}$. "Originality" (or "oorsponkelijkheid") is in Dutch practice typically used as a shorthand for a two-pronged test elaborated by the Supreme Court. The work must have an "own, individual character" and "bear the personal stamp of the author" 328 . In other words, to be original a work needs not only not to be copied from an earlier work, ${ }^{329}$ but it has to be an intellectual creation bearing the "personal stamp" of the author ("eigen oorspronkelijk karakter en een persoonlijk stempel van de maker"). ${ }^{330}$

In particular, the "personal stamp of the author" is present when the work is the result of human creation and of creative choices. Consequently, trivial expressions in which no creativity is involved

323 See Interlego AG v Tyco Industries Inc. [1988] 3 All E.R. 949 at 972.

324 "Ultimately however the composition of the image can be the product of the skill and labour (or intellectual creation) of a photographer and it seems to me that skill and labour/intellectual creation directed to that end can give rise to copyright"; id., at 27.

325 See in this sense Nimmer, at 2.08[E][1] and [2].

326 See Law of 23 September 1912 containing new rules on copyright (Wet van 23 september 1912 houdende nieuwe regeling van het auteursrecht).

327 Dutch Supreme Court, 4 January 1991, NJ 1991, 608, (Van Dale/Romme I).

328 See Spoor et al., 2005, at 59; van Eechoud M., Hugenholtz P., van Gompel S., Guibault L., van der Sloot B., Dutch report, ALAI Study Days, Dublin, June 2011, at 1.

329 Dutch Supreme Court 30 May 2008 ( Endstra/Nieuw Amsterdam).

330 Hugenholtz, 1990, at 29. See also Dutch Supreme Court, 30 May 2008 ( Endstra/Nieuw Amsterdam); Dutch Supreme Court 4 January 1991 (Van Dale/Romme). 
fall outside the scope of copyright protection. ${ }^{331}$ However, according to the Dutch Supreme Court a selection of unprotected elements - such as technical and functional elements, fashion or style - can be copyright-protected if the selection manifests the personal stamp of the author. ${ }^{332}$

Interestingly, the Dutch Supreme Court had the opportunity to explicitly state that its traditional criterion of "own original character and a personal stamp of the author" has the same meaning as the new ECJ harmonised originality requirement of the "author's own intellectual creation". ${ }^{333}$

\subsection{Derivative works}

Article 10-2 of the Dutch Copyright Act states that reproductions in a modified form of a work of literature, science or art, such as translations, musical arrangements, adaptations, and other elaborations, can be protected as original, without prejudice to the primary work. In order to be protected as reproductions in a modified form the listed transformative activities must be original, i.e. they must possesses an "own original character and the personal stamp of the author". Literature is consistent in denying originality to acts such as media shifts or the mere digitisation of works, ${ }^{334}$ or to the conversion of a literary work into another writing form such as Braille since this type of conversion is mere technical. ${ }^{335}$

Likewise, the conversion of a musical work in the form of a midi-file (which necessarily changes the amount of information captured) was found to contain no own personal and original character since the purpose of the specific file format is to capture or record the original work as closely as possible. ${ }^{36}$ Similarly, a correction of a text without creative input is a reproduction and not a new protected work. ${ }^{337}$

Article 13 of the Dutch Copyright Act regulates the right of reproduction (verveelvoudiging) which includes the right of adaptation. The article offers a non-exhaustive list of acts of adaptation which include translation, arrangement of music, cinematographic adaptation or dramatization and generally any partial or total adaptation in a modified form, which cannot be regarded as a new, original work. ${ }^{338}$ To qualify as a protected adaptation a work must be derived from the original work, ${ }^{339}$ which requires that original protected elements are taken over from the primary work. ${ }^{340}$ Stylistic, ${ }^{341}$ technical $^{342}$ and other elements such as ideas, concepts and facts are not protected. Generally, the nature of the initial work has been taken into account to determine the scope of protection in the evaluation of the infringement. ${ }^{343}$

331 Dutch Supreme Court 30 May 2008 ( Endstra/Nieuw Amsterdam), para. 4.5.1.

332 Dutch Supreme Court 23 February 2013 (Stokke/H3 Products) para. 3.4 (e).

333 Dutch Supreme Court 23 February 2013 ( Stokke/H3 Products) para. 4.2.

334 Gielen \& Visser, 2013, Art. 10(9).

335 Spoor et al., 2005, at 133.

336 District Court Utrecht 7 May 1997, (Midi- files); protection could sought in the related right on phonograms.

337 District Court Haarlem 25 January 1983 (Dik Trom).

338 See Spoor, Verveelvoudigen: Reproduction and Apaptation under the 1912 Copyright Act, in Hugenholtz, Quaedvlieg, Visser, 2012, at 206.

339 Dutch Supreme Court 21 February 1992 (Barbie).

340 Dutch Supreme Court 28 June 1946 (Van Gelder/van Rijn).

341 Dutch Supreme Court 29 March 2013 (Broeren/Duijsen).

342 Dutch Supreme Court 16 June 2006 (Lancome/Kecofa) and Dutch Supreme Court 23 February 2013 (Stokke/H3 Products).

343 Dutch Supreme Court 5 January 1979 (Heertje Hollebrand c.s.) para. 5. 


\subsection{Photographic works and non original photographs}

Photographic works are protected by the Dutch Copyright Act, which, however, does not offer specific protection to non original photographs. Photographic works, therefore are protected if they possess an original character and bear the personal stamp of the author. Accordingly, a photograph of a painting featuring the skills of the photographer, but lacking an own creativity would not result in an original work. ${ }^{344}$

However, such original character and personal stamp should not be reason to believe that the threshold of originality is particularly high, as a recent district Court decision finding enough originality in a picture of three shrimps on a plate, seems to suggest. ${ }^{345}$

Nonetheless, a mere technical photograph (a detail of a spout of a watering can) was found to lack the originality required to reach copyright protection. ${ }^{346}$ Another example of lack of original character and personal stamp in a photograph is the Van de Rakt/Chasse Theater case. ${ }^{347}$ In this case, a photograph of a woman lying in the moonlight was almost exactly copied. The minimal differences between the two pictures were found not to constitute the result of creative choices but rather of non-original functional requirements (e.g. specific instructions given by the commissioner) and accordingly the second photograph was not a protectable work in its own right. ${ }^{348}$

\footnotetext{
344 Spoor et al., 2005, at 132.

345 See District Court Limburg, 9 April 2014 (Goudzwaard v Syzygy).

346 Dutch Supreme Court 9 March 1962 (Vitri)

347 Preliminary Court Breda, 8 April 2011 (Van de Rakt/Chasse Theater).

348 Preliminary Court Breda, 8 April 2011 (Van de Rakt/Chasse Theater), para. 7.5.
} 


\section{Part III - Conclusions and recommendations}

\section{2) Conclusions and recommendations}

\subsection{Conclusions}

The goal of this study was to establish whether acts of digitisation are liable to trigger copyright or copyright-related protection under EU law and the law of selected Member States. Three main copyright concepts were accordingly identified and analysed in detail: originality, derivative works and (non) original photographs. The focus of the study was on the operations of cultural heritage institutions, yet the analysis therein developed can be applied to most acts of digitisation.

The main finding presupposes a classificatory distinction. Acts of digitisation should be distinguished between those which merely reproduce an aspect of the reality ("the objective [and the result] is to reach the highest possible grade of identity with the original" ${ }^{349}$ ) and those which carry with an original contribution. While in the former case the availability of new copyright or copyright-related protection can be excluded, in the latter it may be available under certain conditions.

Furthermore, the study demonstrated that the "dimension shifting" factor is a key element in the quest for an original contribution: photographing three-dimensional objects commonly implies more free and creative choices than photographing two-dimensional objects. The reason is quite obvious. Current photographic apparatuses (with few, and for present purposes, irrelevant exceptions) reproduce the photographed items in two dimensions. If the photographed object is in threedimensions, in the passage from three to two dimensions there is a necessary loss of details, aspects, angles, perspectives and other essential elements. Thus, it is often technically impossible to simply reproduce an object, because the current technology does not allow it. Accordingly, a photographer, constrained by technical limitations to reproduce only some of the details or elements to the detriment of others, is requested to operate choices in terms of angles, perspective, lighting, positioning, etc. Depending on the specific situation, these choices can represent the technical know-how of a good technician, or even reach the level of free and creative choices through which the photographer put his personal stamp onto the photographic work.

On the contrary, when the object of the photograph is already in two dimensions (a text, an image, a print, an etching, etc.) the fixation of the original on film or digital support is almost entirely automated, quite similarly to what happens in activities such as reprography and photocopying. In all these cases it is possible to control parameters such as brightness, contrast, or zoom; nevertheless, these modifications do not amount to the author's own intellectual creation necessary for protection. These are cases of mere reproduction, quite similarly to the case of photocopying some pages of a book, being irrelevant whether the brightness or zoom have been adjusted.

Accordingly, under the modern EU originality standard digitisation of two-dimensional items are rarely copyrightable as there is extremely little space for free and creative choices. Conversely, in the case of three-dimensional items there is more leeway for free and creative choices in as much as

349 See AG Opinion in Case C-419/13 [Allposter], at 59. 
the work can be photographed from different angles or with the purpose of privileging a specific side or profile of the item. The more free and creative choices - as exemplified in the discussed French example of the moving object of art - the more likely it is that a court analysing the case will find in favour of the copyrightability of the photograph. However, it is necessary that not only the art of the author of the photographed object is present in the photography, but "also the art of the photographer".

Regarding the peculiar form of protection of "other" photographs, the technical skill or a minimum of intellectual input (instead of the personality) of the maker constitutes the element that usually triggers protection. However, as demonstrated, this type of protection - made possible by Art. 6 Term Directive and implemented in a handful of MS - has not been subject to any harmonisation nor, for that matter, any guidance at the EU level, a situation that lead some commentator to identify it as deficit in harmonisation. ${ }^{350}$ It seems plausible that in countries recognising this peculiar neighbouring right, digitisations of three-dimensional objects and, in limited cases also of twodimensional objects, can find protection when the photographer expresses some appreciable technical skill or minimum intellectual input, without achieving the required EU originality standard. The situation, however, is highly inhomogeneous among the countries offering protection to other photographs.

These conclusions are confirmed by the results of the case studies, which were employed to highlight the distinction between mere reproductions and authorial contributions and in particular the role played by free and creative choices bearing the personal stamp of the author.

Fully automated reproductions - the first case scenario - such as digital photocopies, scanning or other forms of digitisation, conceptually exclude the presence of the author's personal stamp and of his personal choices. Absent an author and his choices, the mechanical act of turning an item into its digital representation constitutes a mere act of reproduction lacking any original input. The protection offered to "other" photographs by national legislation can also be ruled out, as this form of protection requires the presence of either a minimum intellectual input or of the know-how of a technician, and is usually excluded (statutorily or by judicial interpretation) in cases of mere reproduction or reproductive photography. At the same time, a fully automated digitisation is conceivable mostly, if not exclusively, in cases of two-dimensional items. Books, papers, pictures, images, prints and the like are reproduced in a two-dimensional to two-dimensional relationship. All the details of the original can easily be reproduced in the representation and usually acts such as staging or preparation of the object and parameters such as lighting, exposure and perspective are absent or irrelevant in this case. Automatic reproductions of three-dimensional items, on the contrary, are hardly conceivable, as the object needs to be prepared for the digitisation and parameters such as the side, angle, profile, inclination need to be chosen. Here the margin for discretionary choices that will likely influence the result can be ample. In other words, the acts and the conditions just excluded for the case of a two-dimensional item, can in fact acquire relevance in the case of digitisation of three-dimensional objects.

Moving to the third scenario, photographs realised by professional photographers are likewise an "easy" case and even more so when the photographed item is a three-dimensional object. The reason does not obviously lie in the fact that the photographer is "professional". This expression (borrowed from the original Term Directive of '93) served to attract the focus on the relevance of the human (as opposed to mechanic) activity and consequently to the possible presence of free and creative choices. As demonstrated in the study, the choices necessary to digitally (i.e. to twodimensionally) represent a three-dimensional object commonly accrue to the level of originality

\footnotetext{
350 See Benabou, 1997, at 385
} 
required for copyright protection, or, where available, the lower standard of "other" photographs. The syllogism, however, is not automatic. As seen in the country specific analysis, national courts should investigate - and not assume - that in digitally representing something that already exists, such as a work of art, the photographer is in fact operating free and creative choices, and is not merely documenting reality. This finding, for the reasons exposed above, is more likely in cases of digitisation of three-dimensional objects rather than of two-dimensional objects.

Semi-automated digitisations - the second scenario - is clearly a borderline case and therefore of dubious categorisation. Semi-automatic digitisation processes can in fact apply to both twodimensional and three-dimensional objects and involve the role of a human facilitating the process. The guiding principle is once more whether the human involvement in the digitisation is capable to lead to free and creative choices. Similarly to the aforementioned two scenarios, three-dimensional objects are better indicators of these types of choices than two-dimensional items. Nevertheless, the decision should rest on a careful analysis of the role played by the producer of the photographic representation. The relevance of the neighbouring right protecting non original photographs probably reaches its peak in these situations. Cases where a human is involved but where his personal stamp is probably absent (e.g. in the French case of aerial photographs of Paris), might well constitute examples where the protection offered to non-original photographs by other MS could be available. It is worth stressing once more, however, that there is a precise limit to the subsistence of non original photographs: these should not protect mere reproductions or reproductive photography.

In conclusion, automated and semi-automated digitisations (such as scanning, digital photocopying and similar activities) of text and images should be excluded from the protection afforded by copyright and, where it exists, by the related right protecting "other" photographs. In cases of threedimensional items, only a proper assessment of the circumstances of the case can disentangle the complex issue of the protection of photographs and even more of non original photographs of objects of art. The factors to consider in order to address the problem have been exposed in the preceding paragraphs. When the digitisation is carried out by human operators making a whole array of possible choices the resulting image is likely to constitute a protected photograph, instead of a mere reproduction.

From a policy point of view, the study documented how the EU legislature harmonised the originality level for photographic works with a certain success. It would have certainly been desirable that, if really there was a proven need to protect non original photograph, the same legislature had offered a similar kind of guidance instead of favouring the non harmonised situation created by the last sentence of Art. 6. Currently, in the light of a full harmonisation of the concept of originality in the EU, the survival of a peculiar form of protection such as that afforded to "other" photographs, rather than an element of flexibility, appears like a relic of a time when originality and copyright where a matter of national rather than union law. 


\subsection{Recommendations}

\subsection{1) For Cultural Institutions}

1) Cultural institutions interested in digitisation projects should verify the copyright status of the items in their collections. Public domain items can be digitised without infringing third party rights. Where existing, due consideration should be given to special forms of protection such as cultural heritage codes (e.g. Italy and Greece).

2) Digitisation processes can only exceptionally give rise to new copyright or related right protection. Mere digitisation (such as scanning, digital photocopying, photographic reproduction and similar activities) of texts, images and other two-dimensional items are commonly excluded from the protection afforded by copyright and, where it exists, by the related right protecting "other" photographs.

3) When digitising three-dimensional works, only a proper assessment of the specific conditions of the digitisation process and of the status of the digitised items can disentangle the complex issue of the protection of photographs and even more so of non original photographs of objects of art (where available).

4) When proceeding to the digitisation of archives, cultural institution should insert in the contractual agreements with the digitising party clauses securing that the cultural institution is the copyright holder - either original (e.g. work for hire) or derivative (transfer of rights) - of any possible right originating from the digitisation process. This precaution will secure that in the exceptional cases in which such rights may arise the cultural institution owns them.

\subsubsection{For EU and MS legislatures}

5) The European legislature, in view of the full realisation of an internal digital market, should reconsider the opportunity of maintaining the last sentence of Art. 6 Term Directive in its current form. Similarly to other neighbouring rights regulated in the same or in subsequent Directives, the protection for "other" photographs should be object of a direct harmonising intervention. This intervention should either indicate the main features of the right (subject matter, scope, duration, rights and limitations), or - in absence of an enduring need for such type of protection - repeal it.

6) Member States implementing special forms of protection, such as cultural heritage codes, should reconsider the opportunity to maintain those provisions in relation to the parts that create a virtual extension of copyright protection beyond the boundaries established by EU law, thereby eroding the public domain. In particular, the benefits in terms of financial revenues and public access and reuse of cultural heritage of this solution, should be compared with more modern approaches based on public engagement in the reuse of cultural heritage (e.g. the new approach taken by the Rijksmuseum). 


\section{Bibliography}

Angelopoulos C., The Myth of European Term Harmonisation: 27 Public Domains for 27 Member States, in IIC 2012-5, 567.

Arnold R., Copyright in Photographs: a Case For Reform in E.I.P.R. 2005, 303

Autieri P., Floridia G., Mangini V., Olivieri G., Ricolfi M., Spada P., Diritto industriale, properità intellettuale e concorrenza, 4th Ed., Torino, 2012

Benabou V., Droits d'Auteur, Droit Voisins et Droit Communautaire, Brussels, 1997

Bently L., Sherman B., Intellectual Property Law, 4th Ed., Oxford, 2014.

Bently L., The Return of Industrial Copyright?, in E.I.P.R., Vol. 10, September 2012

Bently L., Biron L., Discontinuities between legal conceptions of authorship and social practices What, if anything, is to be done?, in van Eechoud M. (Ed.), The Work of Authorship, Amsterdam, 2014.

Bettink B., Photography and the Law of Copyright, in IIC 1989, 37

Borghi M., Karapapa, S., Copyright and mass digitization, Oxford, 2013

Caso R.,Alle origini del copyright e del droit d'auteur: spunti n chiave di diritto e tecnologia, in Izzo U., Alle origini del copyright e del diritto d'autore: tecnologia, interessi e cambiamento giuridico", Roma, 2010

Cornish W., Llewelyn D., Aplin T., Intellectual Property: Patents, Copyright, Trade Marks, and Allied Rights, 8th Ed., London, 2013

Deazley R., Photographing Paintings in the Public Domain: A Response to Garnett, in 2001 E.I.P.R. 179

Deazley R., Photography, copyright, and the South Kensington experiment, in I.P.Q. 2010, 3, 292331

Derclaye E., Case comment: Infopaq International A/S v Danske Dagblades Forening (C-5/08): wonderful or worrisome? The impact of the ECJ ruling in Infopaq on UK copyright law, in E.I.P.R., 2010, 32(5):247-251 
Derclaye, E. (ed.) Copyright and Cultural Heritage: Preservation and access to works in a digital world, Cheltenham, 2010

Derclaye E., Gervais D., The Scope of Computer Program Protection after SAS: Are We Closer to Answers?, in 2012 E.I.P.R. 565

Derclaye E., The Court of Justice copyright case law: quo vadis?, in 2014 E.I.P.R., 36(11), 716-723

Dietz, The Artist's Right of Integrity Under Copyright Law - A Comparative Approach, in IIC 1994, 177

Fabiani M., La protezione delle fotografie nella legislazione nazionale e nella convenzione di Berna, in Dir. Aut., 1969, N. 4, 529

Fitzgerald B., Atkinson B., (Eds.), Copyright future copyright freedom, Sydney, 2011.

Garnett K., Copyright in Photographs in 2000 E.I.P.R., 229

Geller P., Bently L. (Eds), International Copyright Law and Practice, San Francisco, 2013

Gendreau Y., Nordemann R., Oesch R., Copyright and Photographs. An International Survey, London - The Hague - Boston, 1999

Gervais D., Judge E., Intellectual Property: The Law in Canada, Toronto, 2005.

Gervais D., Feist Goes Global: A Comparative Analysis of the Notion of Originality in Copyright Law, in 49 Copyright Soc'y U.S.A. 949, 2002

Gervais D., The Derivative Right: Or Why Copyright Law Protects Foxes Better than Hedgehogs, 15:4 Vanderbilt Journal of Entertainment and Technology Law 785-855, 2013

Gielen C, Visser D.J.G. (Eds.), Intellectuele Eigendom Tekst en Commentaar, Deventer, 2013

Guibault L., Wiebe A., Safe to Be Open: Study on the Protection of Research Data and Recommendations for Access and Usage, Goettingen, 20013.

Ginsburg J., No 'Sweat?' copyright and other protection of works of information after Feist v. Rural Telephone, in Columbia Law Review, 1992, 92:338-388

Goldstein P., Adaptation Rights and Moral Rights in the United Kingdom, the United States and the Federal Republic of Germany, in IIC 1983, 43

Goldstein P., Hugenholtz B., International Copyright - Principles, Law, and Practice, 3rd Ed., Oxford, 2013

Gordon W., A Property Right in Self-Expression: Equality and Individualism in the Natural Law of Intellectual Property, in The Yale Law Journal, Vol. 102, No. 7, 1993, pp. 1533-1609

Gravells N., Authorship and originality: the persistent influence of Walter v. Lane, in I.P.Q., 2007, $3: 267$ 
Griffiths J., Infopaq, BSA and the 'Europeanisation' of United Kingdom Copyright Law, in Media \& Arts Law Review, Vol. 16, 2011

Griffiths J., Dematerialization, Pragmatism and the European Copyright Revolution, in Oxford Journal of Legal Studies, 2013, 33(4), 767 - 790.

Griffiths J., Constitutionalising or harmonising? The Court of Justice, the right to property and European copyright law, in E.L Rev. 2013, 38(1), 65-78.

Greco P., Vercellone P., I diritti sulle opere dell'ingegno, Torino 1974

Judge E., Gervais D., Of Silos and Constellations: Comparing Notions of Originality in Copyright Law, in 27 Cardozo Arts and Entertainment Law Journal, 2010

Hilty R., Nérisson S. (eds.), Balancing Copyright - A Survey of National Approaches, MPI Studies on Intellectual Property and Competition Law 18, Berlin 2012

Handig C., Infopaq International A/S v Danske Dagblades Forening (C-5/08): is the term "work" of the CDPA 1988 in line with the European Directives?, in E.I.P.R. 2010, 32(2), 53-57

Handig C., The "sweat of the brow" is not enough! - more than a blueprint of the European copyright term "work", in E.I.P.R. 2013, 35(6), 334-340

Hugenholtz B., Quaedvlieg A., Visser D., A Century of Dutch Copyright Law, Amsterdam, 2012

Hugenholtz B., Senftleben M., Fair Use in Europe. In Search of Flexibilities, Amsterdam 2011.

Hugenholtz B., Davison M., Football Fixtures, Horseraces and Spinoffs: The ECJ domesticates the database right, in E.I.P.R., 2005-3, at 113-118

Hugenholtz B., Abuse of Database Right. Sole-source Information Banks under the Database Directive, in Lévêque \& H. Shelanski (eds.), Antitrust, patents and copyright: EU and US perspectives, Cheltenham, 2005

Hugenholtz P., Auteursrecht op informatie, (dissertation 1989) Deventer, 1990

Hughes J., The Photographer's Copyright - Photograph as Art, Photograph as Database, in 25 Harv. J. L. \& Tech. 419 (2011-2012)

Koenraad H., Dutch Supreme Court Tripp Trapp children's chair cases, in Journal of Intellectual Property Law and Practice, 2013, 8(12), 909 - 912.

Kwong J., Photographs of public art in the digital environment, in E.I.P.R. 2014, 36(7), 428-437

Le Stanc C., Intellectual property on Procrustes' bed: observations on a French draft Bill for the protection of "reserved creations", in E.I.P.R. 1992, 14(12), 438-444

Liu D., Of originality: originality in English copyright law: past and present, in E.I.P.R. 2014, 36(6), 376-389 
Lucas A., Lucas H., Lucas-Schloetter A., Traité de la propriété littéraire et artistique, 4th Ed., Paris, 2012

Marchetti P., Ubertazzi L., Commentario breve alle leggi su propreità intellettuale e concorrenza, 5th Ed., Padova, 2012

Margoni T., Not for Designers: On the Inadequacies of EU Design Law and hot to fix it, in JIPITEC Vol. 4, 2013

Margoni T., Perry M., Ownership in Complex Authorship: A Comparative Study of Joint Works in Copyright Law, in E.I.P.R., 2012, 34 (1), 22-32

Masouyé C., Guide to the Berne Convention, Geneve, 1978

Markellou M., Appropriation art under copyright protection: recreation or speculation?, in E.I.P.R. 2013, 35(7), 369-372

Merges R., Locke for the Masses: Property Rights and the Products of Collective Creativity, in 36 Hofstra L. Rev., 2007, p. 1179

Michalos C., The law of Photography and Digital Images, London, 2004

Morando F., F., Cultural Heritage Rights and Open Licenses (i.e. How a Ministerial Decree Can Obliterate the Public Domain in a Country), in Quaderni del Centro Studi Magna Grecia, 2011

Moscon V., Tecnologie, modelli di business e paradigmi giuridici nel diritto d'autore, in Valenti A. (Ed.), Musica e diritto. La legislazione per le attività musicali, Torino, 2012

Nimmer M., Nimmer D., Nimmer on Copyright, San Francisco, 2014

Fromm F., Nordemann A., Urheberrecht, 10th edition, Stuttgart, 2008

Pekel J., Democratising the Rjiksmuseum - Why did the Rijksmuseum make available their highest quality material without restrictions, and what are the results?, Europeana Case Study, 2014

Perry M., Digital Propertisation of the new Artifacts: The Application of Technologies for "Soft" representations of the Physical and Metaphysical, in Cardozo J. of Int'l \& Comp. Law, Vol. $11: 671,2003$, at 696

Perry M., Margoni T., From Music Tracks to Google Maps: Who Owns Computer Generated Works?, in Computer Law and Security Review, Vol. 26, pp. 621-629, 2010

Perry M., Margoni T., Scientific and critical editions of public domain works: an example of European copyright (dis)harmonization, in Canadian Intellectual Property Law Review, 2011, Vol. 27, p. 157

Piola Caselli E., Codice del diritto d'autore. Commentario della nuova legge 22 aprile 1941-XIX, n.633, Torino 1943 
Ramalho A., Conceptualizing the European Union's Competence in Copyright - What Can the EU Do? In IIC 2014, 178

Rahmatian, Originality in UK Copyright Law: The Old "Skill and Labour" Doctrine Under Pressure, in IIC 2013, 4

Rescigno P., Trattato di Diritto Privato, 1983

Ricketson S., Threshold Requirements for Copyright Protection under the International Conventions, in 2009, W.I.P.O. Journal, No. 1, $51-62$

Ricketson S., Ginsburg J., International Copyright and Neighbouring Rights - The Berne Convention and Beyond, 2nd Ed., Oxford, 2005

Rosati E., Originality in a work, or a work of originality: the effects of the Infopaq decision, in Journal of the Copyright Society of the U.S.A., 2011, Vol.58,795-817

Rouland N., Legal Anthropology, London, 1994.

Sarti P., Questioni in tema di fotografie di oggetti materiali, in AIDA, 2000, 612.

Salokannel M. \& Strowel A., Final report: Study contract concerning moral rights in the context of the exploitation of works through digital technology, April 2000

Samuelson P., Vinje T., Cornish W., Does copyright protection under the EU Software Directive extend to computer program behaviour, languages and interfaces?, in E.I.P.R. 2012, 34(3), 158166.

Samuelson P., The Quest for a Sound Conception of Copyright's Derivative Work Right, in UC Berkeley Public Law Research Paper No. 2138479, 2013.

Schricker, Farewell to the "Level of Creativity" (Schöpfungshöhe) in German Copyright Law?, in IIC 1995, 41

Stokes S., Photographing Paintings in the Public Domain: A Response to Garnett in E.I.P.R. 2001, 354

Stokes S., Art and Copyright: some current issues, in Journal of Intellectual Property Law \& Practice, 2008, Vol. 1, No. 4, 272

Spindler G. \& Schuster F., Recht der elektronischen Medien, München, 2011.

Spitz B., Guide to Copyright in France: Business, Internet and Litigation, Amsterdam, 2015.

Ubertazzi L.C., La protezione delle fotografie, in Diritto d'Autore, 1998, 50.

Vaver D., Translation and Copyright: a Canadian Focus, in E.I.P.R. 1994, 16(4), 159-166

Spoor J.H., Verkade D.W.F., Visser D.J.G., Auteursrecht, naburige rechten en databankenrecht, Deventer, 2005 
van Gompel S., Lavik E., Quality, merit, aesthetics and purpose: An inquiry into EU copyright law's eschewal of other criteria than originality, in RIDA - Revue Internationale du Droit d'Auteur, no. 236 (April 2013), pp. 100-295

van Eechoud M., Hugenholtz B., van Gompel S., Guibault L., Helberger N., Harmonizing European Copyright Law - The Challenges of Better Lawmaking, Amsterdam, 2009

van Eechoud M., Along the Road to Uniformity - Diverse Readings of the Court of Justice Judgments on Copyright Work, JIPITEC, 2012-1, p. 60-80, 2012

von Lewinski S., International Copyright Law and Policy, Oxford, 2008

Walter M., von Lewinski S., European Copyright Law: A Commentary, Oxford, 2010

Wotherspoon K., Copyright issues facing galleries and museums, in E.I.P.R. 2003, 25(1), 34-39

Zemer L., The Copyright Moment, in 43 San Diego L. Rev. 247, 287 n.161 (2006) 


\section{Annex I - Tables}

Table I - Countries offering protection to "other" photographs

\begin{tabular}{|c|c|c|c|c|}
\hline Country & Source & Object of protection & Type of protection & Duration \\
\hline Germany & $\begin{array}{l}\text { Art. } 72 \\
\text { Copyright Act }\end{array}$ & $\begin{array}{l}\text { minimum of personal } \\
\text { intellectual input (ein } \\
\text { Mindestmaß an persönlicher } \\
\text { geistiger Leistung) }\end{array}$ & $\begin{array}{l}\text { Same as copyright as } \\
\text { long as compatible } \\
\text { Limited recognition } \\
\text { of moral rights } \\
\text { (paternity). }\end{array}$ & $\begin{array}{l}50 \text { years from } \\
\text { production }\end{array}$ \\
\hline Spain & $\begin{array}{l}\text { Art. } 128 \\
\text { Copyright Act }\end{array}$ & $\begin{array}{l}\text { What is not protected by Art. } \\
10 \text { Copyright Act } \\
\text { (photographic works). } \\
\text { Courts' definition is: } \\
\text { photographs "lacking } \\
\text { creative input". }\end{array}$ & $\begin{array}{l}\text { Reproduction, } \\
\text { distribution, } \\
\text { communication to the } \\
\text { public; No adaptation. } \\
\text { No moral rights }\end{array}$ & $\begin{array}{l}25 \text { years from } \\
\text { production. }\end{array}$ \\
\hline Italy & \begin{tabular}{|l} 
Art. 87 \\
Copyright Act
\end{tabular} & $\begin{array}{l}\text { Technical and professional } \\
\text { skills; " images of persons or } \\
\text { of aspects, elements or } \\
\text { events of natural or social } \\
\text { life, Excluded: writings, } \\
\text { documents, business papers, } \\
\text { material objects, technical } \\
\text { designs and similar products" }\end{array}$ & $\begin{array}{l}\text { Reproduction, } \\
\text { communication, } \\
\text { distribution, and most } \\
\text { likely adaptation. } \\
\text { No moral rights, but } \\
\text { credit name if } \\
\text { indicated. Some } \\
\text { formal requirement to } \\
\text { make remedy } \\
\text { effective. }\end{array}$ & $\begin{array}{l}20 \text { years after } \\
\text { making }\end{array}$ \\
\hline Austria & \begin{tabular}{|l} 
Art. $73-75$ \\
Copyright Act
\end{tabular} & $\begin{array}{l}\text { Photographs which are not a } \\
\text { photographic work, lack } \\
\text { originality and manufactured } \\
\text { by photography or similar } \\
\text { techniques }\end{array}$ & $\begin{array}{l}\text { Assimilated to } \\
\text { copyright (but } \\
\text { reduced in some } \\
\text { respect, such as } \\
\text { adaptation). } \\
\text { Moral rights: } \\
\text { Attribution and } \\
\text { integrity (but reduced } \\
\text { and some formality) }\end{array}$ & $\begin{array}{l}50 \text { after } \\
\text { production }\end{array}$ \\
\hline Denmark & $\begin{array}{l}\text { Art. } 70 \\
\text { Copyright Act }\end{array}$ & $\begin{array}{l}\text { Photographs which are not a } \\
\text { photographic work (lack of } \\
\text { originality) }\end{array}$ & $\begin{array}{l}\text { Reproduction and } \\
\text { making available to } \\
\text { the public. Attribution } \\
\text { and integrity. }\end{array}$ & $\begin{array}{l}50 \text { since the } \\
\text { picture was } \\
\text { taken }\end{array}$ \\
\hline Finland & $\begin{array}{l}\text { Art. 49A } \\
\text { Copyright Act }\end{array}$ & $\begin{array}{l}\text { Photographs which are not a } \\
\text { photographic work (lack of } \\
\text { originality) }\end{array}$ & $\begin{array}{l}\text { Reproduction in } \\
\text { original and modified } \\
\text { form and making } \\
\text { available to the }\end{array}$ & $\begin{array}{l}50 \text { since the } \\
\text { picture was } \\
\text { made }\end{array}$ \\
\hline
\end{tabular}




\begin{tabular}{|l|l|l|l|l|}
\hline & & & $\begin{array}{l}\text { public. Attribution } \\
\text { and integrity. }\end{array}$ & \\
\hline Iceland & $\begin{array}{l}\text { Art. 49 } \\
\text { Copyright Act }\end{array}$ & $\begin{array}{l}\text { Photographs which are not a } \\
\text { photographic work (lack of } \\
\text { originality) }\end{array}$ & $\begin{array}{l}\text { Reproduction making } \\
\text { available to the } \\
\text { public. }\end{array}$ & $\begin{array}{l}50 \text { years since } \\
\text { picture was } \\
\text { taken (Act No. } \\
9 / 2006, \text { Art. } \\
12 \text { ). }\end{array}$ \\
\hline Norway & $\begin{array}{l}\text { Art. 43a } \\
\text { Copyright Act }\end{array}$ & $\begin{array}{l}\text { Photographs which are not a } \\
\text { photographic work (lack of } \\
\text { originality) }\end{array}$ & $\begin{array}{l}\text { Reproduction and } \\
\text { making available to } \\
\text { the public. Attribution } \\
\text { and integrity }\end{array}$ & $\begin{array}{l}15 \text { p.m.a. (but } \\
\text { min. 50) }\end{array}$ \\
\hline Sweden & $\begin{array}{l}\text { Art. 49 } \\
\text { Copyright Act }\end{array}$ & $\begin{array}{l}\text { Photographs which are not a } \\
\text { photographic work (lack of } \\
\text { originality) }\end{array}$ & $\begin{array}{l}\text { Reproduction and } \\
\text { making available to } \\
\text { the public in original } \\
\text { or altered form. } \\
\text { Attribution and } \\
\text { integrity. }\end{array}$ & $\begin{array}{l}50 \text { after } \\
\text { production }\end{array}$ \\
\hline
\end{tabular}




\title{
Annex II - Questionnaire
}

\author{
Europeana Awareness - A EU comparative legal study on the concepts of originality, \\ digitization, and derivative works in copyright law.
}

Questionnaire

\section{Introduction}

The objective of this questionnaire is to help Europeana Awareness find answers to the thorny question of whether the digitization of images (painting, drawings, maps, photos, etc.), texts (books, newspapers, letters, etc.), objects (statues, sculptures, vases, coins, etc.), films, phonograms, and TV or radio broadcasts (altogether "the covered subject matter), gives rise to copyright or copyrightrelated protection. Many times, in fact, cultural institutions participating in the Europeana network do not apply a public domain mark or a $\mathrm{CCO}$ waiver to the files they contribute alleging that such digital representations of - often public domain - works enjoy some form of copyright or copyrightrelated protection of which they are not the right-holders. While the expressed concerns deserve the greatest attention and analysis, it is this project's work-hypothesis that in many instances these digital reproductions are in the public domain and they should be accordingly redistributed. In order to verify and hopefully confirm our work-hypothesis it is unavoidable to define the precise boundaries of some copyright law key concepts for all the $28 \mathrm{EU}$ countries. Accordingly, we have drafted the following questionnaire and subdivided it into two parts. In the first part we ask 4 general and open-ended questions on four key concepts of copyright law: originality, derivative works, and existence and scope of protection of non-original material by ad-hoc related rights (such as the protection of non original photographs offered by some jurisdiction in addition to the protection afforded to photographic works). In the second part of the questionnaire we ask a number of multiple choice questions that focus specifically on the type of activity that leads to the digitization process and the type and status of the material that is to be digitized.

Thank you in advance for your help in replying to this questionnaire, it represents an incredibly valuable contribution towards the goal of a more open use and reuse of information and knowledge.

\section{$\underline{\text { Part I - General open questions }}$}

Please answer the following questions in the given space (max 1 page per question). Please cite correctly and extensively (e.g.: avoiding abbreviations and acronyms) any legal sources you refer to such as laws, acts, decrees, case law, green papers, articles in journals, etc. Please also offer an online link to the original text when available. Additionally, if available in English, please also provide a link to the English version.

1) Please indicate the definition and/or relative standard of "originality" in your country on the basis of a) statutory definition, and b) case law (please indicate specific decisions especially if they address the subject matter covered by this research). Please also indicate if the standard as 
implemented by courts has been subject to substantial modifications after the ECJ Infopaq-Painer jurisprudence).

2) Please indicate the definition and/or standard of "derivative works" or equivalent (modifications, adaptations, elaborations, abridgement, translation, media shifting, etc.) in your country on the basis of a) statutory definition, and b) case law, with particular attention to specific cases that relate to the covered subject matter.

3) Please indicate whether the law of your country recognizes a neighbouring right for non-original photographs and what the conditions of protection are (criteria, duration, scope, etc.), on the basis of a) statutory definition and b) case law. In case of positive answer, please indicate whether nonoriginal photographs also include scans of books or of photographs.

4) Please indicate if the law of your country (statutes and case law) specifies the scope of protection for film's first fixations, phonograms, and TV/Radio broadcasts, and in particular whether acts of digitization or remasterization of the originals are covered by the scope of the rights and therefore require right-holders' authorization.

\section{$\underline{\text { Part II - Multiple choice }}$}

Please answer by indicating the legal status of the act of digitization for any given subject matter and also indicate in whom the copyright or related right - if any - will vest. If there is any additional information that needs to be reported for a correct and complete answer, please use the space below the table.

Basic case:

A major museum of your country is interested in digitizing its entire collection and to make it available to the public. The collection is vast and includes among other items: images (painting, drawings, maps, photos, etc.), texts (books, newspapers, letters, etc.), objects (statues, sculptures, vases, coins, etc.), audiovisual and cinematographic works, phonograms, and TV and radio broadcasts.

Some of these materials are in the public domain (because either they were never protected or because the term of protection has expired), while others are still protected by copyright or related rights. In order to proceed, the museum needs to know whether, for copyright purposes, the "digitization" of the following material leads to the creation of an independent work, of a derivative work, of a material covered by a specific neighbouring or similar right, or leads to something not covered by copyright law. Equally important is to know, in cases where a new right comes into existence, who is the right-holder.

\begin{tabular}{|c|c|c|c|}
\hline Action & Category of work & $\begin{array}{l}\text { Indicate if the result is: } \\
\text { - an independent work } \\
\text { (C); } \\
\text { - a derivative work } \\
\text { (D); } \\
\text { - protected by a related } \\
\text { right (please specify); }\end{array}$ & $\begin{array}{c}\text { Please indicate who is } \\
\text { the right-holder of the } \\
\text { newly created right, if } \\
\text { any }\end{array}$ \\
\hline
\end{tabular}




\begin{tabular}{|c|c|c|c|}
\hline & & - not protected (PD) & \\
\hline \multirow{12}{*}{$\begin{array}{l}\text { Automated } \\
\text { reproduction/digitizatio } \\
\text { n realized in absence } \\
\text { (or negligible presence) } \\
\text { of human intervention } \\
\text { (e.g.: Google scanning } \\
\text { automatically all books } \\
\text { of the entire } \\
\text { collection). }\end{array}$} & Texts: protected & & \\
\hline & $\begin{array}{l}\text { in the public } \\
\text { domain }\end{array}$ & Not protected & \\
\hline & Images: protected & & \\
\hline & domain ${ }^{\text {in the public }}$ & & \\
\hline & Objects: protected & & \\
\hline & domain ${ }^{\text {in the public }}$ & & \\
\hline & Broadcasts: protected & & \\
\hline & domain in the public & & \\
\hline & $\begin{array}{l}\text { Films' fixations: } \\
\text { protected }\end{array}$ & & \\
\hline & domain in the public & & \\
\hline & Phonograms: protected & & \\
\hline & domain in the public & & \\
\hline \multirow{4}{*}{$\begin{array}{l}\text { Automated } \\
\text { reproduction realized } \\
\text { by human operator } \\
\text { (e.g.: human operator } \\
\text { taking } \\
\text { pictures/manually } \\
\text { photocopying } \\
\text { collections for } \\
\text { inventory/classificatory } \\
\text { purposes) }\end{array}$} & Texts: protected & & \\
\hline & domain in the public & & \\
\hline & Images: protected & & \\
\hline & in the public & & \\
\hline
\end{tabular}




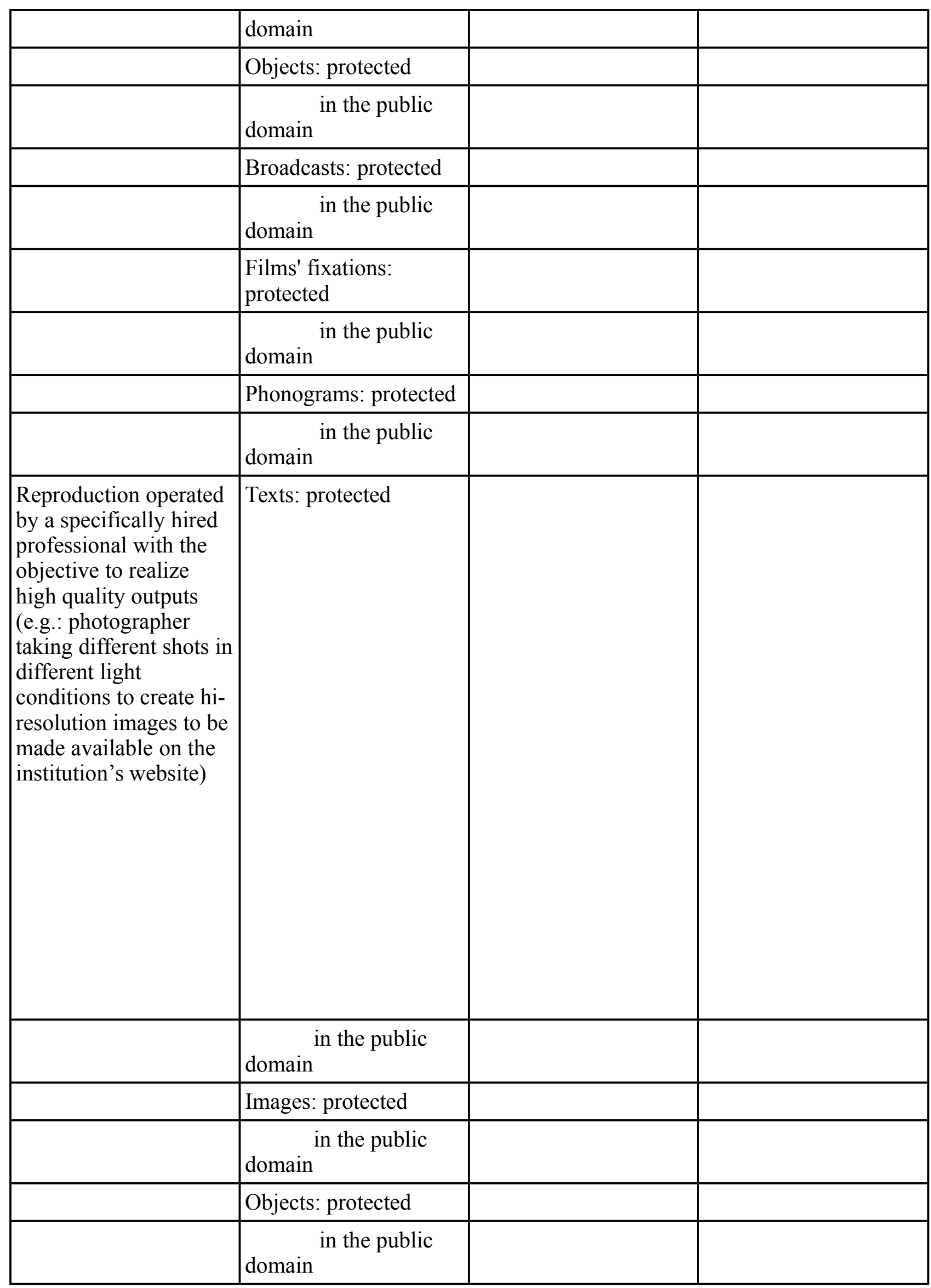




\begin{tabular}{|l|l|l|l|}
\hline & Broadcasts & & \\
\hline & domain in the public & & \\
\hline & Films' fixations & & \\
\hline & domain in the public & & \\
\hline & Phonograms & & \\
\hline & domain in the public & & \\
\hline
\end{tabular}

Additional remarks: Please use the given space in order to indicate any additional consideration regarding the multiple choice part. This space should be used in particular by those jurisdictions featuring special form of protection (e.g.: non-original photographs) which are not included in the multiple choice list above. 


\section{Annex III - List of national correspondents}

\begin{tabular}{|l|l|}
\hline Austria & N/A \\
\hline Belgium & N/A \\
\hline Bulgaria & Teodora Tsenova, Djingov, Gouginski, Kyutchukov \& Velichkov (DGKV), Sofia \\
\hline Cyprus & Tatiana Eleni Synodinou, University of Cyprus \\
\hline Czech Republic & Tomáš Dobřichovský, Charles University, Kř́ž \\
\hline Croatia & Vanja Kovacevic - Attorney at law \\
\hline Denmark & Maria Fredenslund, RettighedsAlliancen \\
\hline Estonia & Elise Vasamäe, Aavik \& Partners Law Office, Tallinn \\
\hline Finland & Ville Oksanen, Aalto University \\
\hline France & Brad Spitz, YS Avocats, Paris \\
\hline Germany & Benjamin Schütze, Leibnitz Universität, Hannover \\
\hline Greece & Tatiana Eleni Synodinou, University of Cyprus \\
\hline Hungary & Dr. Eszter Kabai, head of Legal Department at Artisjus \\
\hline Ireland & N/A \\
\hline Italy & Valentina Moscon, University of Trento \\
\hline Latvia & Magda Papēde, Dr. iur. candidate at the University of Freiburg \\
\hline Lithuania & Jeanine Rizzo, Fenech \& Fenech Advocates, Valletta \\
\hline Metherlands & Anne Thier-Goubitz, IViR \\
\hline
\end{tabular}




\begin{tabular}{|l|l|}
\hline Norway & $\begin{array}{l}\text { Irina Eidsvold Tøien, Norwegian Research Center for Computers and Law, } \\
\text { University of Oslo }\end{array}$ \\
\hline Poland & $\begin{array}{l}\text { Krzysztof Siewicz - Interdisciplinary Centre for Mathematical and } \\
\text { Computational Modelling (ICM), University of Warsaw. }\end{array}$ \\
\hline Portugal & $\begin{array}{l}\text { Alexandre L.D. Pereira, Law Faculty and Institute for Legal Research, Coimbra } \\
\text { University, Portugal }\end{array}$ \\
\hline Romania & N/A \\
\hline Slovakia & Martin Husovec, European Information Society Institute, Vranov \\
\hline Slovenia & Maja Bogataj Jančič, Intellectual Property Institute (IPI), Ljubljana \\
\hline Spain & Raquel Xalabarder - Univresitat Oberta de Catalunya \\
\hline Sweden & Katarina Renman, Faculty of Law, Stockholm \\
\hline Switzerland & Yaniv Benhamou, Lenz \& Staehellin, Geneva \\
\hline United Kingdom & Stavroula Karapapa, University of Reading \\
\hline
\end{tabular}

